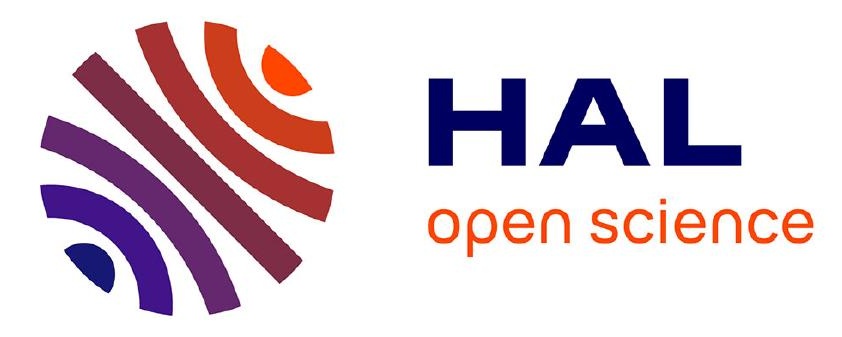

\title{
Swelling pressure development and inter-aggregate porosity evolution upon hydration of a compacted swelling clay
}

Luc Massat, Olivier Cuisinier, Isabelle Bihannic, Francis Claret, Manuel Pelletier, Farimah Masrouri, Stéphane Gaboreau

\section{To cite this version:}

Luc Massat, Olivier Cuisinier, Isabelle Bihannic, Francis Claret, Manuel Pelletier, et al.. Swelling pressure development and inter-aggregate porosity evolution upon hydration of a compacted swelling clay. Applied Clay Science, 2016, 124-125, pp.197 - 210. 10.1016/j.clay.2016.01.002 . hal-01409015

\section{HAL Id: hal-01409015 \\ https://hal.univ-lorraine.fr/hal-01409015}

Submitted on 5 Jul 2019

HAL is a multi-disciplinary open access archive for the deposit and dissemination of scientific research documents, whether they are published or not. The documents may come from teaching and research institutions in France or abroad, or from public or private research centers.
L'archive ouverte pluridisciplinaire HAL, est destinée au dépôt et à la diffusion de documents scientifiques de niveau recherche, publiés ou non, émanant des établissements d'enseignement et de recherche français ou étrangers, des laboratoires publics ou privés. 


\section{Swelling pressure development and inter-aggregate porosity evolution}

\section{2 upon hydration of a compacted swelling clay}

3

4

5

Luc Massat $^{\mathrm{a}, \mathrm{b}, \mathrm{c}}$, Olivier Cuisiniera ${ }^{\mathrm{a}, \mathrm{b}, *}$, Isabelle Bihannic ${ }^{\mathrm{d}, \mathrm{e}}$, Francis Claret $^{\mathrm{c}}$, Manuel Pelletier ${ }^{\mathrm{d}, \mathrm{e}}$, Farimah Masrouria $^{\mathrm{a}, \mathrm{b}}$, Stéphane Gaboreau ${ }^{\mathrm{c}, *}$

${ }^{a}$ CNRS, LEMTA, UMR 7563, Vandoeuvre-lès-Nancy F-54500, France

${ }^{b}$ Université de Lorraine, LEMTA, UMR 7563, Vandoeuvre-lès-Nancy F-54500, France

${ }^{c}$ BRGM, Bureau de recherches géologiques et minières, Orléans, France

${ }^{d}$ CNRS, LIEC, UMR7360, Vandoeuvre-lès-Nancy F-54500, France

${ }^{e}$ Université de Lorraine, LIEC, UMR7360, Vandoeuvre-lès-Nancy F-54500, France

${ }^{*}$ Corresponding author at:

LEMTA, Université de Lorraine-CNRS, UMR 7563, 2 rue du Doyen Marcel Roubault,TSA 70605, 54518 Vandœuvre-lès-Nancy Cedex, France. E-mail address: Olivier.Cuisinier@ensg.univ-lorraine.fr (O. Cuisinier).

BRGM, Water, Environment and Ecotechnologies Division, 3 avenue Claude Guillemin, 45060 Orléans Cedex 2, France. E-mail address: s.gaboreau@brgm.fr (S. Gaboreau). 


\section{Abstract}

A specific oedometer cell has been set up to measure the swelling pressure of compacted montmorillonites at constant volume and to concomitantly visualize the evolution, upon wetting, of how the microstructure is organised through X-ray microtomography. The swelling pressure experiments were conducted with solvents of various natures. In addition to conventionally used water and saline solutions, we used an organic solvent (methyl methacrylate - MMA). We chose this to explore the effect of its different physical and chemical properties, and to differentiate the respective roles of crystalline and osmotic pressures on macroscopic swelling behaviour.

The results, which combined both swelling pressure measurements and quantification of microstructure evolution upon hydration for the two different solutes, give sound understanding on the development of osmotic and/or crystalline swelling and their relative impact both on the microstructure and on the magnitude of the macroscopic swelling pressure of compacted montmorillonites. 


\section{Introduction}

Clays are of importance for many geo-mechanical environments: they are ubiquitous on Earth's surface, where they play an important role in soil stability. They are also commonly used as engineered barriers or backfill materials in the design of waste disposal repositories (Kaufhold et al., 2015). The main properties that swelling clays such as smectites offer to limit pollutant transfer and ensure the mechanical stability of engineered constructions include ion adsorption capacity, sealing ability, and low permeability. Depending on the context, fluids of different natures (e.g. alkaline, acid, salty) may interact with clay materials. We need to understand the driving force responsible for the underlying clay swelling to optimize engineered barrier behaviour. Therefore, to assess performance, we have to understand swelling pressure development in situations close to field conditions.

Swelling behaviour in bentonites is mainly related to the presence of montmorillonites, a clay mineral made of 2:1 layer structure in which one octahedral sheet is sandwiched between two tetrahedral layers (Figure 1). Due to isomorphous substitutions involving either the tetrahedral or the octahedral sheet, the clay unit layer bears a structural negative charge, which is balanced by cations adsorbed on layer surfaces in the interlamellar spaces. The particular behaviour of clay with respect to water or aqueous solutions results from cation hydration, but is also influenced by how the sheets are turbostratically stacked to form particles (Bergaya and Lagaly, 2013).

For a clay system in contact with an aqueous solution or a humid atmosphere, two main processes contribute jointly to control the overall swelling in the materials: crystalline swelling and osmotic swelling (Laird et al., 1995; Madsen and Müller-Vonmoos, 1989; Norrish, 1954). Crystalline swelling happens at the nanometric level for the lowest water contents (undersaturated systems). From an initially dry state, hydration occurs on the most energetic sites, i.e. on unit layer surfaces (both on particles' external interfaces and in interlayer spaces) and on interlayer cations (Bérend et al., 1995; Cases et al., 1992; Rinnert et al., 2005). This latter phenomenon of cation solvation results in the successive adsorption of several water layers in the interlamellar spaces and leads to separation of clay unit layers that can be followed by the measurement of the basal spacing $\left(\mathrm{d}_{001}\right)$ using X-ray diffraction (XRD). 
Several authors, for instance Lloret et al. (2003), Ferrage et al. (2005), Likos and Wayllace (2010), Holmboe et al. (2012) and Villar et al. (2012), have shown that for Na-montmorillonites the basal spacing $\mathrm{d}_{001}$ evolves from $9.7 \AA$ in the dry state to $12.6 \AA, 15.6 \AA$ and $18.6 \AA$ corresponding to one, two, or three water layers, respectively, as the relative humidity increases. Crystalline swelling is influenced by different parameters such as interlayer cation nature, relative humidity or water activity, dry density and swelling conditions (free or confined) (Di Maio, 1996; Di Maio et al., 2004; Imbert and Villar, 2006; Karnland et al., 2011; Karnland et al., 2008; Karnland et al., 2006; Karnland et al., 2007; Kaufhold et al., 2015; Komine and Ogata, 1994, 1996, 2003; Komine et al., 2009; Lloret et al., 2003; Pusch, 1982; Schanz and Tripathy, 2009; Sridharan et al., 1986; Studds et al., 1998; Villar et al., 2012; Villar and Lloret, 2008).

In addition to crystalline swelling, the other process that comes into play during hydration is osmotic swelling. This occurs for higher water contents (water activities above 0.8-0.9 and in saturated systems) and corresponds to a further ingress of water in the materials (Madsen and Müller-Vonmoos, 1989). The driving force for osmotic swelling is the repulsion between the electrical diffuse double-layers that form on platelet surfaces (Chapman, 1913; Gouy, 1917; Gouy, 1910; Stern, 1924). For smectites exchanged with monovalent cations, osmotic swelling manifests itself by clay platelet separation distances larger than $40 \AA$ and that can progress continuously towards infinity for very dilute suspensions (Meleshyn and Bunnenberg, 2005; Michot et al., 2004; Norrish, 1954). For divalent smectites (Ca- or Mgmontmorillonite), osmotic swelling seems to be prohibited in the interlayer spaces due to strong ion-ion correlation forces that reduce double-layer repulsion (Kjellander et al., 1988; Wang et al., 2011). For divalent montmorillonite, the greatest basal spacing measured does not exceed $19 \AA$ (Holmboe et al., 2012; Michot et al., 2013; Norrish, 1954). Even if basal distances are limited to $19 \AA$, Camontmorillonite may continue to accommodate additional water that cannot enter the interlamellar spaces and that is found outside particles. This phenomenon is called "inter-particle osmotic swelling" and is linked to osmotic forces that may exist on the particles' outer surfaces (Madsen and MüllerVonmoos, 1989; Segad et al., 2010), meaning that the interlamellar spaces are not the only places that play an important role in the swelling behaviour of clay materials but particles' external surfaces have also to be taken into account (Laird, 2006; Liu, 2013; Madsen and Müller-Vonmoos, 1989). 
From this we conclude that regardless of the swelling mechanism and whatever the cation nature, hydration will induce major reorganization in both the clay fabric and the associated porosity. That is why we must refer to porosity when we speak of swelling.

Many studies (Bihannic et al., 2009; Bihannic et al., 2001; Cases et al., 1992; Keller et al., 2013; Likos and Wayllace, 2010) have focused on the porosity description. They used various investigative techniques (XRD, SAXS/SANS, FIB/SEM, MIP), and from those results, we can schematically consider the total porosity to be composed of pores of different sizes (Figure 1) such as the interlayer space, the porosity between particles (inter-particle porosity) and the porosity between aggregates (inter-aggregate porosity). The effect of hydration on microstructure has been described (Delage et al., 2006; Devineau et al., 2006; Tang et al., 2011; Van Geet et al., 2005) but often only considering one or two porosity levels, e.g. inter-aggregate and/or interlayer porosity. Globally, for sodium-dominated clays, hydration leads to widening of interlayer spaces with an associated decrease in inter-aggregate porosity. Some authors (Kozaki et al., 2001; Pusch and Yong, 2006; Tomioka et al., 2010) explain this process by the formation of gel structure on the outer part of the particle/aggregate and/or by exfoliation of the particles (Cui et al., 2002; Pusch, 1982). Indeed it has been observed that hydration leads to a decrease in the number of layers per particle (Bérend et al., 1995; Perdrial and Warr, 2011; Saiyouri et al., 2004). Hydration has consequences on clay microstructure organisation and pore distribution, and consequently it also impacts materials' mechanical properties, especially in confined or compacted conditions. In that case, as macroscopic swelling is prevented, swelling pressure develops in the materials. Its amplitude is again related to the nature of the exchangeable counterions and the ionic strength of the solutes, but also to the material’s dry density. Some authors (Brackley, 1973; Gens et al., 2011; Imbert and Villar, 2006; Pusch, 1982; Schanz and Tripathy, 2009) have shown that for samples with dry density of between 1.2 and $2.0 \mathrm{Mg} / \mathrm{m}^{3}$, swelling pressure behaviour upon wetting is non-monotonic. It reaches a peak, then falls significantly and rises to a value that remains stable over time. Push (1982) suggested that this behaviour could be related to the clay fabric being modified upon hydration. Validating this hypothesis remains difficult as most of the microstructural studies are conducted either on samples submitted to a specific preparation procedure (freeze drying, solvent exchange, etc.) that may have altered their fabric (Delage et al., 2006; Holzer et al., 2010), or without any concomitant determination of materials' macroscopic 
mechanical properties (Van Geet et al., 2005). Most of the time microstructures are only observed once the sample reached the final steady state, without intermediate observations between the beginning of wetting and the final stage.

These kinds of experimental conditions limit the understanding of the relationships between fabric modifications upon wetting and swelling pressure development but it has been established that this mechanical behaviour is influenced by water uptake (Harjupatana et al., 2015) and induced physicochemical phenomena occurring at different porosity scales: (1) interlayer, (2) inter-particle and (3) inter-aggregate (Bérend et al., 1995; Laird, 2006; Madsen and Müller-Vonmoos, 1989; Perdrial and Warr, 2011; Saiyouri et al., 2004).

In this context, the main objective of our study was to analyse the relationship between swelling pressure development and the associated microstructure evolution induced by wetting. A new oedometer cell, transparent to X-ray, was designed both to monitor swelling pressure over time and to visualise interaggregate porosity changes through X-ray micro-computed tomography $(\mu \mathrm{CT})$, on a unique specimen. During $\mu \mathrm{CT}$, the mechanical constraint was kept on the sample, thus limiting disturbance related to its preparation (e.g. sample decompaction, or sample dehydration). A commercially purified montmorillonite was used to perform the experiments. Homo-ionic water solutions with two ionic strengths and a polar organic solvent were considered to analyse the relative impact of osmotic and crystalline swellings on the clay fabric and to tentatively relate microstructural changes to swelling pressure development.

\section{Material and methods}

\subsection{Kunipia-G, Japanese swelling clay}

A smectite provided by Kunimine Industries was used for this study (Table 1). This material, available as Kunipia-G grade, is a highly pure montmorillonite (>95\%) (Fukushima, 1984; Kozaki et al., 1999; Sato, 2008; Sato et al., 1992; Wilson et al., 2004) and has among others the advantage of avoiding long purification steps to remove secondary mineral phases. Powder X-ray diffraction (XRD) patterns indicate traces of quartz and carbonates (Figure 2). Examination of the 060 band at $1.49 \AA \AA$ indicates that 
Kunipia-G is a dioctahedral smectite. XRD patterns obtained on oriented preparations recorded in airdried conditions after ethylene glycol solvation or after temperature increase $\left(550^{\circ} \mathrm{C}\right)$ show that (i) the basal spacing recorded in the air-dried state is compatible with a Na interlayer counterion, (ii) a rationality of the 001 reflections (Figure 2a) proving the absence of illite/smectite mixed layered minerals. The cation exchange capacity (CEC) determined by the chloride cobaltihexamine displacement method (Orsini and Rémy, 1976) is 115 mequiv/100g with the following distribution of exchangeable cations: $\mathrm{Na}$ 91\%, $\mathrm{Ca} \quad 8 \%$, K $1.0 \%$. The chemical formula, $\mathrm{Na}_{0.41} \mathrm{~K}_{0.01} \mathrm{Ca}_{0.04}\left(\mathrm{Si}_{3.92} \mathrm{Al}_{0.08}\right)\left(\mathrm{Al}_{1.51} \mathrm{Mg}_{0.37} \mathrm{Fe}_{0.12}\right) 0_{10}(\mathrm{OH})_{2}, \mathrm{nH}_{2} \mathrm{O}$, derived from X-ray fluorescence (XRF), is compatible with previous studies (Fukushima, 1984; Sato, 2008; Sato et al., 1992; Wilson et al., 2004). The dry particle density of Kunipia-G is $2.71 \mathrm{Mg} / \mathrm{m}^{3}$.

The specific surface area determined from a nitrogen adsorption experiment using the BET equation (Brunauer et al., 1938) is $42 \mathrm{~m}^{2} / \mathrm{g}$, similar to the specific surface area (SSA) founded by Kozaki et al. (1999). The water sorption isotherms (data not shown) have a typical shape for swelling clays and particularly for Na-exchanged smectites, with two steps on the water adsorption curve (Cases et al., 1992). Considering the desorption branch of the water isotherm, and assuming that in this state all the interlayers are accessible, applying BET formalism gives an estimated total surface area of around 524$660 \mathrm{~m}^{2} / \mathrm{g}$. This estimation agrees with the ethyleneglycolmonoethylether (EGME) measurement (Kozaki et al., 1999).

\subsection{Experimental strategy: new tomographic oedometer to follow both}

\section{swelling pressure and inter-aggregate pore evolution}

\subsubsection{Tomographic oedometer cell features}

A new oedometer device has been developed to continuously monitor swelling pressure during the hydration process, and to image, at selected swelling stages, the specimen structure using X-ray microcomputed tomography ( $\mu \mathrm{CT}$ ) (Figure 3). The designed cell has been built with polyether ether ketone (PEEK), which is a material with limited X-ray attenuation and that can sustain high swelling pressure with very low deformation. TECAPEEK CF 30 grade, provided by Ensinger ${ }^{\circledR}$, was used due to its improved mechanical strength with 30\% carbon fibre (Young’s modulus: 18.5 GPa, yield stress: 
$215 \mathrm{MPa}$ ). The cell is composed of three parts: a ring and two pistons. Compared to standard oedometer cells, the sample diameter was reduced to $10 \mathrm{~mm}$ in order to obtain the best possible resolution taking into account the shape and size constraints (distance of the sample relative to the X-ray source and to the charge coupled device (CCD)). The initial sample height was set at $10 \mathrm{~mm}$. The dimensions of the complete device were adapted to the available space in the X-ray tomograph (Phoenix Nanotom ${ }^{\circledR}$ ). Under these conditions, $\mu \mathrm{CT}$ images were recorded with a voxel size of 5 micrometres.

\subsubsection{Simultaneous in situ measurement of both swelling pressure and sample microstructure at the X-ray tomography scale}

The cell was placed on a load frame to monitor sample swelling pressure. The solution was injected (50 $\mathrm{kPa}$ ) at the lower side of the sample with a pressure-volume controller. All the tests were performed under constant volume conditions. A closed-loop control kept the sample height constant, i.e. we had constant volume conditions, by adjusting the vertical load exerted on the sample during the wetting. All the experiments were conducted at a temperature of $20 \pm 1.5^{\circ} \mathrm{C}$. Vacuum was imposed inside the pistons before the beginning each test to avoid air bubbles being trapped at the base of the sample, or in the lower piston.

An experimental protocol was defined to remove the cell from the loading frame to perform X-ray tomography acquisition. It consisted in stopping fluid injection, screwing the cell to prevent any volumetric sample deformation and placing the whole in the tomograph. The entire scanning process lasted between 3 and 4 hours. In total, five points were selected at specific times on the swelling curve. The impact of that protocol on material behaviour has been assessed and is discussed later in this paper.

\subsubsection{Image processing and inter-aggregate porosity (at a $5 \mu \mathrm{m}$ resolution scale)} extraction

Images were recorded using a Phoenix Nanotom ${ }^{\circledR}$ tomography system and its $180 \mathrm{kV} / 20 \mathrm{~W}$ nanofocus X-ray tube. Scans were performed at $80 \mathrm{kV}$ and $75 \mu \mathrm{A}$ with 2880 projections to cover $360^{\circ}$ (angle step of $0.125^{\circ}$ ). During X-ray tomography scans, the Coupled Charge Device (CCD) recorded the intensity I of the X-ray beam passing through the specimen to reconstruct a 3D-volume after mathematical reconstruction based on back-projection. 
Each voxel of the reconstructed volume (8-bit) is characterized by its intensity value ranging on a greyscale from 0 (black) to 255 (white), which is linked to the X-ray attenuation by the specimen: the

201

202

203 higher the attenuation, the higher the intensity, i.e. a solid medium (such as our Kunipia-G) has a higher grey value than macropores. For each sample, a sub-volume of the same size (450 x 1400 x 1800 pixel $\left.^{3}\right)$ was extracted from the same position (Figure 4a). The aim was to reduce the amount of data we had to analyse and to optimize the volume of interest (VOI). The VOIs are $9 \mathrm{~mm}$ tall (1800 pixels) excluding $0.5 \mathrm{~mm}$ at both ends of the sample because the conical shape of the beam means these parts are not illuminated similarly to the rest of the sample.

The inter-aggregate porosity was quantified along the height of the specimen (z-profile) using an image analysis procedure that was adapted to extract the pores from the solid skeleton of the 3D computed volumes. Image quality was first enhanced by applying (i) a contrast and brightness adjustment spreading the histogram and (ii) a classic Gaussian Blur 3D filter with a radius of 2 pixels to reduce noise. To separate these pores from the surrounding clay matrix, the maximum gradient magnitude, which is equivalent to the inflection point of the smooth intensity profile across the interface (due to the insufficient resolution), was enhanced by optimizing the edge of the transition between pores and solid grains. The sharp transition of the greyscale profile across the solid/pore interface was restored from the actual smooth profile by using a local weighted filter. This sharpening filter does not transform the edge position of the object but improves sharpness by increasing acutance (Sheppard et al., 2004). A watershed algorithm (Vincent and Soille, 1991) was then used to separate the pore from the solid in the gradient greyscale images. The watershed separations (markers belonging to the pores and solid) were selected by identifying the slope change of the grey level histogram on its first derivative (Gaboreau et al., 2016; Prêt et al., 2010a; Prêt et al., 2010b). The result of this segmentation at the initial dry state is illustrated in Figure 4.

In addition, a morphological characterisation of the pore space distribution with pore size distribution (PSD) was performed using a public domain software iMorph (http://imorph.fr/). The characterization was done in five regions of interest (ROI) of same height $(1.8 \mathrm{~mm})$ along the z-profile from bottom to top (ROI1 being close to the solvent inlet at the specimen bottom and, ROI5 at the top). 


\subsubsection{Comparison with standard constant volume oedometers}

In order to validate the results obtained with the new tomographic oedometer cell, constant volume oedometers were used to characterize the swelling behaviour of Kunipia-G specimens in standard conditions. The basic principle of these devices is to allow sample hydration and to maintain the sample at constant volume while measuring swelling pressure. On the lower side of the specimen, hydration occurs by diffusion during the entire test duration, and the solution is renewed with a peristaltic pump. The height of the sample in these devices was set at $10 \mathrm{~mm}$ for diameters of $50 \mathrm{~mm}$ or $34 \mathrm{~mm}$. More details on these standard oedometer cells are available in Cuisinier (2002).

\subsection{Experimental procedure}

\subsubsection{Sample preparation and compaction}

The dry density of the specimens compacted in the tomographic cell was set to $1.40 \pm 0.02 \mathrm{Mg} / \mathrm{m}^{3}$, corresponding to a theoretical total porosity $\emptyset$ of $48 \%$ according to the following equation:

$$
\emptyset=1-\frac{\rho_{d}}{\rho_{s}}
$$

where $\rho_{\mathrm{d}}$ is the dry density $\left(\mathrm{Mg} / \mathrm{m}^{3}\right)$ and $\rho_{\mathrm{s}}$ is the particle density $\left(\mathrm{Mg} / \mathrm{m}^{3}\right)$.

The specimens were statically compacted from a crushed and sieved dry Kunipia-G powder ( $1 \mathrm{~mm})$ (oven-dried at $105^{\circ} \mathrm{C}$ ) at a speed of $1.14 \mathrm{~mm} / \mathrm{min}$, to the desired dry density.

\subsubsection{Solvent selection}

To assess the effect of the solvents on swelling pressure, two aqueous solutions $(\mathrm{NaCl})$ at two different ionic strengths $\left(10^{-1}\right.$ and $\left.10^{-4} \mathrm{M}\right)$ and an organic solvent (methyl methacrylate, MMA) were used. Saturation with $\mathrm{NaCl}$ solutions was to evaluate the coupled development of crystalline and osmotic swelling. In our case, at full saturation, considering the chosen dry density $\left(1.4 \mathrm{Mg} / \mathrm{m}^{3}\right)$, the intercalation of two to three-water layers in the interlayer spaces is estimated (Holmboe et al., 2012; Villar et al., 2012), regardless of the ionic strength of the solution. Salt concentration is mainly expected to affect osmotic phenomena.

MMA was also selected for its physical properties close to those of water (Table 2). MMA is widely used to impregnate finely divided solids (Gaboreau et al., 2012; Gaboreau et al., 2011; Gaboreau et al., 2016; Prêt et al., 2010a; Prêt et al., 2010b; Prêt et al., 2004; Pusch and Schomburg, 1999; Sardini et al., 
2009). Given its properties, impregnated MMA samples are described as mimicking a hydrated microstructure (Prêt et al., 2010b; Pusch, 1999; Sammartino et al., 2002) with the intercalation of MMA molecules in clay interlayer spaces (Prêt, 2003; Prêt et al., 2010b). Such behaviour is mainly due to MMA's low viscosity and its dipolar moment close to that of water. Indeed, MMA, like water, is a polar molecule, so apparently leads to interlayer hydration (Blumstein et al., 1970; Tabtiang et al., 2000). A smectite powder saturated with MMA displays basal spacing $d_{001}$ of $17.2 \AA$ (Blumstein, 1965; Prêt, 2003), characteristic of two layers of MMA in the interlayer, mainly though electrostatic dipole-ion interaction with the ester functional group. This was confirmed by powder X-ray diffraction patterns of Kunipia-G samples saturated with MMA (Figure $2 b$ ), where $d_{001}$ was found to be $17.1 \AA$. This $d_{001}$ value is equivalent to a hydration state between two and three water layers when hydration is performed with water solutions. Moreover, no osmotic swelling is detected with MMA, while in the same XRD acquisition conditions (free swelling in a huge solution volume) with a $10^{-3} \mathrm{M} \mathrm{NaCl}$ solution, large basal $\mathrm{d}_{001}$ spacings have been measured, corresponding to osmotic swelling leading to around $21 \AA$, equal to four layers of water molecules (Holmboe et al., 2012; Michot et al., 2004). Further experiments undertaken at the macroscopic scale showed that the interaction of MMA molecules with clay induced swelling pressure in compacted clay specimens (Pusch, 1999). Therefore, using MMA was a good means of assessing the swelling pressure and the porosity evolution mostly controlled by the influence of the crystalline swelling component, as the osmotic pressure was hindered.

\subsubsection{Measurement approach}

First of all, experiments were conducted to validate the new oedometer tomographic cell. This was based on comparing results obtained with standard oedometer cells, and literature data. The impact of sample size and the tomography procedure were assessed. These experiments were conducted using $\mathrm{NaCl} 10^{-4}$ M solution.

Once the cell was validated, experiments were performed to characterise the impact of fluid features on swelling pressure development and on the associated porosity reorganisation. Five experiments were undertaken with compacted Kunipia-G specimens at dry density of $1.4 \pm 0.02 \mathrm{Mg} / \mathrm{m}^{3}$ using the tomographic cells. Two experiments were conducted with $\mathrm{NaCl} 10^{-4} \mathrm{M}$ solutions and two others used $\mathrm{NaCl} 10^{-1} \mathrm{M}$, the last run being acquired with MMA. For each run, X-ray tomography scans were 
performed at the initial and final states. Intermediate scans were only performed for one specimen of each $\mathrm{NaCl}$ ionic strength. In those cases, a first acquisition (t0) was performed just after compaction. Four different scans (t1, t2, t3, t4) were performed to obtain intermediate hydrated states at particular specific times on the swelling pressure curve. The last scan (t5) was performed once steady state conditions were reached. Intermediate scans with MMA as wetting fluid were not conducted because of the high kinetics of hydration process.

\section{Results}

\subsection{Assessment of the tomographic cell measurements}

\subsubsection{Comparison with standard oedometers}

The swelling pressure measured over time and swelling pressure values at steady state for both the standard oedometer cells and the new tomographic cell were compared. In this sub-section, all the experiments were performed with $\mathrm{NaCl} 10^{-4} \mathrm{M}$ solutions. Swelling pressure first developed a peak reached after a few days (Table 3) and then a plateau (Figure 5a). After the peak, the swelling pressure fell to around $10 \%$ of the peak value. Steady state conditions (second maximum value) were then reached. Typically the first peak was obtained between 7.7 and 10.2 days while the steady state occurred after 38 and 48 days. The first maximum was comprised between approximately 1.9 and 2.2 MPa while the steady state values are comprised between 2.7 and 3.5 MPa. The first maximum typically occurred at around $20 \%$ of the time needed to reach the steady state and corresponded to about $60 \%$ of the stable swelling pressure value. In all cases, the swelling pressure curves obtained with the Kunipia-G hydrated with $\mathrm{NaCl} 10^{-4} \mathrm{M}$ solutions were typical of those described in the literature (Gens et al., 2011; Imbert and Villar, 2006; Komine and Ogata, 2003; Pusch, 1982; Schanz and Tripathy, 2009).

The steady state values, i.e. at final stage of the test, were compared to existing literature data obtained with two other types of clays, and to data obtained on Kunipia-G for densities ranging between 1.2 and $1.75 \mathrm{Mg} / \mathrm{m}^{3}$ (Table 3 and Figure $5 \mathrm{~b}$ ). At a dry density of $1.40 \mathrm{Mg} / \mathrm{m}^{3}$, the difference between swelling pressure at peak and at steady state is limited whatever the specimen size (10, 34, $50 \mathrm{~mm}$ diameter with tomographic, pressure and injection cell respectively). These results are in line with the study of Gens et al. (2011), Komine et al. (2009), Imbert and Villar (2006) or Volckaert et al. (1996) working with 
oedometer cells at different sample sizes. They demonstrated that the size of the sample, diameter rather than height, modifies the kinetics of swelling pressure upon hydration (slower for longer specimens), but does not significantly impact the magnitude of swelling pressure (difference at peak and at final state). Based on these conclusions, a dimensionless representation of the curve displaying the swelling pressure versus time has been used previously to facilitate sample comparison. The y-axis corresponds to the ratio of swelling pressure to swelling pressure at the plateau and the $\mathrm{x}$-axis is the ratio between time to the time of peak occurrence.

\subsubsection{Effect of intermediate tomography scans}

The impact of intermediate tomography scans was assessed by comparing swelling pressure curves determined in the new oedometer cell of specimens hydrated by $10^{-4} \mathrm{M}$ and $10^{-1} \mathrm{M} \mathrm{NaCl}$ with and without intermediate scans (Figure 6 and Table 3). Swelling pressure curves of samples subjected to tomography scans fit well to the swelling pressure evolution of the test undertaken without tomography acquisition. As described previously, swelling pressure evolution is non-monotonic: the peak swelling pressure reached around $65 \%$ of the swelling pressure at steady state with or without intermediate scans. Slight differences over time are observed for the specimen hydrated by $\mathrm{NaCl} 10^{-1} \mathrm{M}$ solution. The kinetics of swelling pressure over time of this specimen subjected to intermediate tomography scans were slightly impacted by the intermediate scans, but the peak appearance was at $20 \%$ of the total time to reach the plateau as it was with the other tests and the swelling pressure value at the peak is comparable (68\% of the final value).

Thus, the experimental procedure used to assess both swelling pressure and porosity with intermediate scans has limited impacts on swelling pressure development in the compacted samples as a function of time from the beginning of hydration.

\subsection{Effect of fluid features on swelling pressure}

\subsection{1 $\mathrm{NaCl}$ hydration at various ionic strengths}

The shapes of the swelling pressure curves for specimens hydrated with $10^{-1} \mathrm{M} \mathrm{NaCl}$ solutions (Figure 6) are similar to those recorded with $10^{-4} \mathrm{M} \mathrm{NaCl}$ solutions. The non-monotonic behaviour is also observed, with a peak before reaching a stable plateau. The swelling pressure peak was observed at a 
time equivalent to $20 \%$ of the time needed to reach the maximum, and the value corresponded to about $66 \%$ of the final pressure irrespective of ionic strength (Table 3). Nonetheless, we see (Figure 7) that the higher the ionic strength, the lower the swelling pressure at peak and at steady state (30\% lower with Na $10^{-1} \mathrm{M}$ than Na $10^{-4} \mathrm{M}$ ). These results, in accordance with previous studies (Karnland et al., 2006; Karnland et al., 2007; Pusch, 1982), are related to the development of repulsion between the electrical double layers whose thickness is reduced at higher ionic strength (Norrish, 1954; Santamarina et al., 2002). Consequently, the osmotic pressure also falls at higher ionic strength.

\subsubsection{MMA hydration}

With MMA injections, swelling pressure increases sharply over time, almost instantaneously, to reach a plateau within a few minutes (Figure 7). The maximum swelling pressure value is significantly higher (3.10 MPa) with MMA as hydrating fluid than those measured with $10^{-4}$ or $10^{-1} \mathrm{M} \mathrm{NaCl}$ solutions. The experiment was stopped sooner than for the samples hydrated with $\mathrm{NaCl}$ solutions since the steady state was reached after 15 days. The slight variations observed in steady state can be explained by the sensitivity of MMA fluidity to slight temperature variations in the room $\left(20^{\circ} \mathrm{C} \pm 1^{\circ} \mathrm{C}\right)$.

\subsection{Tomography results}

The X-ray tomography images recorded for the Na $10^{-4} \mathrm{M}$ specimen are displayed in Figure 8a. For clarity, only four times were selected. The fabric observed in the initial state before the beginning of hydration is an entangled multi-layered structure, characterized by darker zones that may be assigned to pores. The pores are anisometric and ellipsoidal and the largest are some hundreds of microns long and a few tens of microns wide. Pores are oriented with their biggest size perpendicular to the compaction axis. This type of layered structure is uniformly distributed throughout the entire specimen. For the first point visualized during hydration, which is in the rise of the curve before the peak (t1), some changes are observed in the lower part of the image. The contrast between pores and the particles that separate them is greatly reduced, giving an impression of a homogeneous structure. This lowest part of the specimen is the one that is first hydrated by water. As hydration and swelling progress, this homogeneous zone extends on the image, with some tenuous remaining traces of the initial status in the 
360

361

362

363

364

365

366

367

upper part of the images recorded at $\mathrm{t} 3$ (minimum position after the peak) and then complete homogenisation on the plateau (t5).

While the same porosity modification trends can be observed for the sample hydrated with the second ionic strength (Figure 8b), the evolution is different with MMA. With MMA, due to the rapid increase in swelling pressure, only the final state was imaged (Figure 8c). Wetting with MMA does not lead to the homogenization observed with water. Contrasting zones remain, with a shape and orientation that seem more isotropic than in the initial state. The distribution along the vertical axis is uniform, without the gradients that were observed in the intermediate steps during water hydration.

To analyse $\mu \mathrm{CT}$ pictures further, an image pre-processing step (see section 2.2.3) was applied for binarizing the images and extracting inter-aggregate porosity. The porosity as defined corresponds to the areas that have sufficient contrast with respect to the clay matrix to be distinguished from it, and have spatial resolution greater than 5 microns. For the initial states after compaction, the $\mu \mathrm{CT}$ porosity calculated in this manner corresponds to $38-39 \%$ of the total volume of the specimen whose total theoretical porosity is $48 \%$. These results are very comparable to other swelling clay like the case of MX-80 as shown by Gens et al. (2011) at the same dry density from MIP data (inter-aggregate porosity: 37\%, total porosity: 48\%). This means that the thresholding procedure is valid for estimating the interaggregate porosity, in agreement with results found in the literature and derived using other techniques (MIP, nitrogen adsorption) on different swelling clays.

In addition, we deduce the inter-aggregate porosity evolution versus specimen height (Figure 9a and Table 4). Initially, a slight inter-aggregate porosity gradient is observed along the vertical axis inside the specimen. The inter-aggregate porosity increased from about $37 \%$ on the top up to more than $45 \%$ on the bottom. Both ends are also slightly over-compacted. This is related to the compaction procedure, and this effect has been well described in the case of compacted soils (Eslami, 2014; Tisot, 1974; Winter and Clarke, 2002). These effects of the compaction procedure were comparable for all the samples prepared in the context of that study. From morphological analysis (Table 5), the gradient is also noticeable with a pore size reduction in the upper part of the sample (ROI 3 to 5). In this initial state, the mean aperture radius is of $15.6 \mu \mathrm{m}$. 
The $\mu \mathrm{CT}$ inter-aggregate porosity profiles derived at the intermediate stages of hydration with Na $10^{-4}$ M solution show that the swelling pressure development is associated with reduced inter-aggregate porosity. For $\mathrm{t} 1$ and t2, this porosity decrease is not uniform along the specimen z-axis: the reduction is much greater in the lower part of the specimen, i.e. close to the water inlet (from $45 \%$ in the initial state to a few percent in the hydrated state), whereas less uniform inter-aggregate porosity reduction occurred in the upper part of the sample (porosity is reduced by half for distances greater than $6 \mathrm{~mm}$ from the inlet). Between these two zones a gradient was observed. On average, more than $75 \%$ of the interaggregate porosity volume was reduced when the first peak of swelling pressure was reached. At t3 the inter-aggregate porosity distinguishable with $\mu \mathrm{CT}$ was lower than $3 \%$, and this time corresponded to the minimum swelling pressure reached after the first peak. The swelling pressure increased between $\mathrm{t} 3$ and the final stage occurred without any major change to porosity profile except a slight decrease in the mean value: the profiles display similar shapes at $\mathrm{t} 3$ and at the end of the test. The decrease of the detected porosity is also combined to a reduction of the inter-aggregate pore size (Table 5). At $\mathrm{t} 1$ and $\mathrm{t} 2$, the reduction of the inter-aggregate pore size is greater in the lower part of the specimen (mean aperture radius around $8.0 \mu \mathrm{m}$ ) than in the upper part (mean aperture radius around $12.0 \mu \mathrm{m}$ ). At t3, no difference is observed between lower and upper part with a mean aperture size of $8.0 \mu \mathrm{m}$. After t3, a slight decrease of pore size is noticed (mean aperture size of $7.5 \mu \mathrm{m}$ ).

The impact of ionic strength is less obvious on the $\mu \mathrm{CT}$ porosity profiles (Figure $9 \mathrm{~b}$ and Table 4) and the pore morphology (data not shown) than on the swelling pressure values.

In the case of the sample hydrated with MMA, only the scans before and at the end of the tests were performed. At the end, some macropores defined by a size larger than $5 \mu \mathrm{m}$ and a contrast different from the clay matrix, still remained, all over the specimen height (Figure 9c). A slight gradient was observed, probably resulting from sample preparation. The average porosity was about $8 \%$; this value was significantly higher than the one derived after water hydration (Table 4). At this final state, the pore morphology (Table 5) shows also the gradient with bigger pore size in the lower part (ROI1) than in the upper part of the specimen (ROI5). The final state of the specimens hydrated by MMA is associated with larger pores at $8.1 \mu \mathrm{m}$. 


\section{Discussion}

Kunipia-G’s swelling pressure was monitored for two different solvents (sodium chloride and MMA). In the case of $\mathrm{NaCl}$, the ionic strength has been varied from $10^{-4}$ to $10^{-1} \mathrm{M}$. During swelling pressure development, changes in the structure (inter-aggregate pores) were visualised using micro-tomography. The main experimental observations are the following (Figure 10):

- in the case of MMA, the swelling pressure abruptly increases before levelling off. On the contrary, for hydration with a $\mathrm{NaCl}$ solution, the swelling pressure first increases, reaches a local maximum, then decreases and rises until reaching a plateau (Figure 7);

- for $\mathrm{NaCl}$, the maximum value reached at the plateau is lower for the highest ionic strength, whereas the shape of the swelling pressure curve does not depend on the salt concentration (Figure 7);

- a correlation exists between the fabric heterogeneities observed in the sample at the resolution of tomographic scans (inter-aggregate pores) and the macroscopic evolution of the swelling pressure;

- although in the case of MMA it is still possible to detect some inter-aggregate porosity by X-ray tomography at the apparatus' resolution $(5 \mu \mathrm{m})$ even on the steady state, for $\mathrm{NaCl}$, whatever the ionic strength, the inter-aggregate porosity has disappeared at the dip that appears after the swelling pressure decreases and before it increases again (Figure 9). Nevertheless, in all the cases, the decrease of inter-aggregate porosity is linked to an evolution of the initial anisotropic pore distribution with the obvious development of pores with size lower than the resolution.

Some of these differences observed between samples hydrated by water solution or by MMA can be explained by MMA's properties. In particular its low viscosity and low surface tension (Table 2) increase the wettability of the solvent injection in the sample and consequently the swelling pressure kinetics.

The following discussion focused on the experimental results summarised above, aims at understanding (i) the inter-aggregate porosity changes and (ii) the non-monotonic swelling pressure evolution with peak occurrence. 


\subsection{Processes responsible for inter-aggregate porosity decrease}

441

442

443

444

445

446

447

448

449

450

451

452

453

As already discussed in the introduction, the main processes that generally operate in concert to control bentonite swelling in aqueous systems are crystalline (interlayer) swelling and osmotic swelling (both double-layer at the inter-particle and the inter-aggregate level); the second process leading to break-up the initial dry particles into thinner ones. Based on the work of Liu (2013), these two contributions can be evaluated from its model for the Kunipia-G material used in this study (Figure 11a). Whereas the crystalline pressure is empirically related by an exponential law (see equation 26 and the related one in Liu (2013)) to the length of the diffuse double layer (DDL) between two montmorillonite particles (reflecting the decay of the hydration forces as the distance increases), the osmotic pressure can be derived by applying the Gouy-Chapman theory according to the following equation issued from Liu (2013).

$$
\mathrm{P}_{\mathrm{DDL}}=2 \mathrm{cRT}\left(\cosh \mathrm{y}^{\mathrm{m}}-1\right)
$$

Where $\mathrm{c}$ is the ionic concentration of the pore solution in $\mathrm{mol} / \mathrm{m}^{3}, \mathrm{R}$ is the gas constant, $\mathrm{T}$ is the absolute temperature in Kelvin and $\mathrm{y}^{\mathrm{m}}$ is the scaled midplane potential at the midpoint between unit layers.

In this approach, an important parameter, the Deybe length, which can be considered as an estimate of the double layer thickness, has to be used. The Debye length is square root dependent on the relative dielectric constant of the pore solution. Considering that MMA's relative dielectric constant is about 12 times lower than water's (6.32 versus 78.54, see Table 2), calculation shows (Figure 11b) that for a dry density of $1.4 \mathrm{Mg} / \mathrm{m}^{3}$, the osmotic pressure developed with MMA is one order of magnitude lower than that obtained with water $\left(\mathrm{NaCl}\right.$, both $10^{-4}$ and $\left.10^{-1} \mathrm{M}\right)$, reaching a negligible pressure (0.4 MPa) compared to the total pressure measured (3 MPa).

The first conclusion that can be derived from this simple calculation is that in the case of MMA the main process that operates is crystalline swelling. The second is that, in the case of sodium chloride solution, the calculated osmotic pressure is approximately 2.65 MPa for ionic strength of $10^{-4} \mathrm{M}$ and 2.16 for $10^{-}$ ${ }^{1} \mathrm{M}$. These values are very close to the values that are measured during our experiment after reaching a steady state (Figure 7 and Figure 11b). Introducing crystalline pressure into the calculation of total swelling pressure slightly increases this value, and strongly suggests that for saline solutions, the main 
contribution at the working density is given by osmotic processes (Figure 11a and b). In the case of MMA, crystalline pressure cannot be calculated because no isotherm data are available with MMA but it contributes mainly to the total swelling pressure as the osmotic component is negligeable (Figure 11b). Hydration of Kunipia-G specimens by saline solutions induces particle breakup due to osmotic component with major aggregate reorganisation. This could explain partly the inter-aggregate porosity reduction seen by $\mu \mathrm{CT}$ (Figure 8a and b). In contrast, for specimens hydrated by MMA, only crystalline swelling occurs which does not lead to particle breakup, probably explaining the slighter inter-aggregate porosity decrease observed by $\mu \mathrm{CT}$ (Figure 8c). The assumption made concerning particle breakup leading to inter-aggregate filling is confirmed by literature results (Perdrial and Warr, 2011; Saiyouri et al., 2004), nevertheless further investigations at lower scale (FIB/SEM, TEM) may ensure that (currently conducted).

\subsection{Explanation of peak occurrence}

Several assumptions have been made to describe the non-monotonic swelling behaviour of smectiterich material related to inter-aggregate pore evolution. For instance, Pusch (1982) related the swelling pressure peak to the formation of gel structures upon wetting that modify the mechanical characteristics of aggregates/particles (shear strength) and decrease the swelling pressure. This has been integrated by Alonso et al. (1999) in the Barcelona Expansive Model (BExM), with the progressive reorganisation of the internal structure of samples upon wetting. Progressive filling of the macrostructure (inter-aggregate void ratio decrease) occurred. Gens et al. (2011) modelled this process, based on tests performed on FoCa clay compacted at $1.45 \mathrm{Mg} / \mathrm{m}^{3}$. They showed that the modelled non-monotonic swelling pressure is linked to the modelled reorganisation of inter-aggregate porosity. This reorganisation is progressive upon wetting with remaining inter-aggregate porosity of $25 \%$ at the end of the test. Figure 12 shows that the kinetics of observed inter-aggregate porosity decrease of our Kunipia-G's specimen wetted by $\mathrm{NaCl}$ $10^{-4} \mathrm{M}$ agree with the evolution of the FoCa clay at different specimen heights (lower, middle and upper part). Nevertheless the extent of the porosity decrease is different, with almost total filling of the interaggregate porosity with the Kunipia-G sample. A possible explanation for this difference may be linked 
to the difference in mineralogy of both materials. FoCa is only made of $45 \%$ swelling clay, the remaining mineral being kaolinite, whereas Kunipia-G contains 95\% of smectite. Another explanation could be relied to the BBM definition with the interaction function between microstructure elastic deformation and macrostructure plastic deformation.

Thus, from our results and the above comparison with BExM model, we can suppose the non-monotonic behaviour with peak occurrence is related to the progressive inter-aggregate porosity reorganisation. This may be linked directly to the particle-solvent interaction introduced previously in the discussion, in other words to the crystalline and osmotic swellings.

Regarding hydration processes, Wang et al. (2013) conducted wetting experiments on a specimen composed of a 7/3 MX80/quartz dry mass mixture to assess the evolution of the relative humidity versus specimen height. They concluded that specimens hydrated by aqueous solutions are not subject to the same water transfer between the lower part in contact with fluid and the upper part. Liquid water transfer occurs in the lower part whereas above the hydration front vapour water transfer prevails (Pusch and Yong, 2003). Moreover, Ichikawa et al. (2004) have followed the change in d spacing with an in situ XRD apparatus called a 1-D consolidometer for a dry density of $1.4 \mathrm{Mg} / \mathrm{m}^{3}$ and loading of $1.9 \mathrm{MPa}$ (close to the measured swelling pressure in our experiment). They have described two consolidation stages. Firstly, external pore water is drained, and the state of three water layers' hydration causes a large displacement; secondly two water layers of hydration are detected, increasing with time; and finally in the final stage the water layers of hydration remain constant while the displacement is still increasing. In this latter stage the interlayer water is drained. In the case of MMA the intercalated layers are always limited to two, leading to basal spacing mimicking 2-3 water layers. Like vapour water hydration (Tang et al., 2011), the intercalation of two MMA molecule layers into the interlayer spacing (Figure 2b) leads to swelling of particles filling up the inter-particle porosity with limited closure of inter-aggregate porosity. Such swelling development without the momentary decrease of swelling pressure over time has been also observed under RH regimes when particle swells without total interaggregate porosity filling (Likos and Wayllace, 2010; Tang et al., 2011). Instead of microstructure reorganisation in between the aggregates, the intercalation of water layers inside and between particles leads to their swelling, which fills up the inter-aggregate pores. Depending on the ionic strength this 
521

particle reorganisation can be described as gel formation with the exfoliation of particles situated on the outer surface of the aggregates (Kozaki et al., 2001; Pusch and Yong, 2006; Tomioka et al., 2010). We should note that this explanation only stands for monovalent cations, and solutions with low ionic strength.

Considering these data, osmotic component $\left(\mathrm{P}_{\mathrm{DDL}}\right)$ is mainly the physical driving force leading to the reorganization of the microstructure and cumulative mechanisms are responsible for the non-monotonic swelling pressure evolution upon hydration. Visualising the structure by tomography corroborates the assumption of reorganization already made, mainly when osmotic phenomena may develop. Unfortunately, the spatial resolution of this technique does not allow qualifying or quantifying this new arrangement at a smaller scale.

\section{Conclusion}

In this study, the specific experimental procedure conducted with a newly designed innovative oedometer allowed us to assess the evolution of swelling pressure and inter-aggregate porosity upon hydration at the same time (and for the first time as far as we know). From X-ray tomography scans and image post-processing, we can correlate between both parameters. The inter-aggregate porosity diminished from the start of the test until the minimum after the peak is reached. Then, water redistribution inside the structure leads to reaching a stable swelling pressure. Moreover, controlling the swelling pressure at a particle scale via the use of various fluids ( $\mathrm{NaCl}$ at two ionic strengths and MMA) aimed to differentiate between the impact of crystalline swelling and osmotic swelling on swelling pressure development. Two behaviours of swelling pressure developments were observed according to the different solvents with non-monotonic and monotonic evolutions according to saline solutions and MMA inlets, respectively. Because this non-monotonic behaviour is not seen with MMA, where calculation has shown that the osmotic pressure is negligible (crystalline contribution), the nonmonotonic swelling pressure development was found to be due to the osmotic pressure under the hydration front of the compacted sample, leading to reorganisation of the microstructure with filling of part of the inter-aggregate porosity; combined phenomena could be both responsible for the drop in 
548

549

550

551

552

553

554

555

556

swelling pressure. A comparison with the BExM model shows a similar correlation between swelling pressure and inter-aggregate porosity reorganisation upon wetting.

Further investigations performed on a smaller scale (from $\mu \mathrm{m}$ to $\mathrm{nm}$ ) will allow assessment of the interaggregate pores of size smaller than $5 \mu \mathrm{m}$ and the number of layers per particle at full saturation in compacted samples and will lead both to improvement in how we understand our system and to connections across the different scales.

\section{Acknowledgments}

The work was conducted within the framework of an InterCarnot thesis (ICEEL-BRGM). We are deeply grateful for the support of the NEEDS MIPOR consortium (CNRS, ANDRA, CEA, EDF, BRGM) and that of Région Lorraine.

We thank C. Morlot for his participation in microtomography measurements performed at GEORESSOURCES (UMR 7359, CNRS-Université de Lorraine). We thank F. Demeurie, J-Y. Morel and the LEMTA's engineering team for their help in experimental device development. We thank F. Villieras, J. F. L. Duval, Z.G. Yigzaw, C. Chiaberge and C. Tournassat for fruitful and stimulating discussions. 
Alonso, E.E., Vaunat, J., Gens, A., 1999. Modelling the mechanical behaviour of expansive clays. Engineering Geology 54, 173-183.

Bérend, I., Cases, J.M., François, M., Uriot, J.P., Michot, L., Masion, I.A., Thomas, F., 1995. Mechanism of adsorption and desorption of water vapor by homoionic montmorillonites: 2. The Li+, $\mathrm{Na}+, \mathrm{K}+, \mathrm{Rb}+$ and $\mathrm{Cs}+-$ exchanged forms. Clays and Clay Minerals 43, 324-336.

Bergaya, F., Lagaly, G., 2013. Handbook of clay science. Newnes.

Bihannic, I., Delville, A., Demé, B., Plazanet, M., Villiéras, F., Michot, L., 2009. Clay Swelling: New Insights from Neutron-Based Techniques, in: Liang, L., Rinaldi, R., Schober, H. (Eds.), Neutron Applications in Earth, Energy and Environmental Sciences. Springer US, pp. 521-546.

Bihannic, I., Tchoubar, D., Lyonnard, S., Besson, G., Thomas, F., 2001. X-Ray Scattering Investigation of Swelling Clay Fabric: 1. The Dry State. Journal of Colloid and Interface Science 240, 211-218. Blumstein, A., 1965. Polymerization of adsorbed monolayers. I. Preparation of the clay-polymer complex. Journal of Polymer Science Part A: General Papers 3, 2653-2664.

Blumstein, A., Malhotra, S.L., Watterson, A.C., 1970. Polymerization of monolayers. V. Tacticity of the insertion poly(methyl methacrylate). Journal of Polymer Science Part A-2: Polymer Physics 8, 15991615.

Brackley, I., 1973. Swell pressure and free swell in compacted clay, 3rd International Conference of Expansive Soils. National Building Research Institute, Council for Scientific and Industrial Research, Haifa, pp. 169-176.

Brunauer, S., Emmett, P.H., Teller, E., 1938. Adsorption of gases in multimolecular layers. Journal of the American Chemical Society 60, 309-319.

Cases, J.M., Berend, I., Besson, G., Francois, M., Uriot, J.P., Thomas, F., Poirier, J.E., 1992. Mechanism of adsorption and desorption of water vapor by homoionic montmorillonite. 1. The sodium-exchanged form. Langmuir 8, 2730-2739.

Chapman, D.L., 1913. A contribution to the theory of electrocapillarity. The London, Edinburgh, and Dublin Philosophical Magazine and Journal of Science 25, 475-481. 
Cui, Y., Loiseau, C., Delage, P., 2002. Microstructure changes of a confined swelling soil due to suction controlled hydration, Proceedings of the 3rd International Conference on Unsaturated Soils (UNSAT 2002), Recife, Brésil. Sous la direction de J. FT Jucá, TMP de Campos et FAM Marinho, pp. 593-598. Cuisinier, O., 2002. Comportement hydromécanique des sols gonflants compactés. Institut National Polytechnique de Lorraine-INPL.

Delage, P., Marcial, D., Cui, Y., Ruiz, X., 2006. Ageing effects in a compacted bentonite: a microstructure approach. Géotechnique 56, 291-304.

Devineau, K., Bihannic, I., Michot, L., Villiéras, F., Masrouri, F., Cuisinier, O., Fragneto, G., Michau, N., 2006. In situ neutron diffraction analysis of the influence of geometric confinement on crystalline swelling of montmorillonite. Applied Clay Science 31, 76-84.

Di Maio, C., 1996. Exposure of bentonite to salt solution: osmotic and mechanical effects. Géotechnique 46, 695-707.

Di Maio, C., Santoli, L., Schiavone, P., 2004. Volume change behaviour of clays: the influence of mineral composition, pore fluid composition and stress state. Mechanics of Materials 36, 435-451.

Eslami, H., 2014. Comportement thermo-hydromécanique des sols au voisinage des géo-structures énergétiques.

Ferrage, E., Lanson, B., Sakharov, B.A., Drits, V.A., 2005. Investigation of smectite hydration properties by modeling experimental X-ray diffraction patterns: Part I. Montmorillonite hydration properties. American Mineralogist 90, 1358-1374.

Fukushima, Y., 1984. X-ray diffraction study of aqueous montmorillonite emulsions. CLAYS CLAY MINER. Clays Clay Miner. 32, 320.

Gaboreau, S., Lerouge, C., Dewonck, S., Linard, Y., Bourbon, X., Fialips, C.I., Mazurier, A., Pret, D., Borschneck, D., Montouillout, V., Gaucher, E.C., Claret, F., 2012. In-situ interaction of cement paste and shotcrete with claystones in a deep disposal context. American Journal of Science 312, 314-356. Gaboreau, S., Prêt, D., Tinseau, E., Claret, F., Pellegrini, D., Stammose, D., 2011. 15 years of in situ cement-argillite interaction from Tournemire URL: Characterisation of the multi-scale spatial heterogeneities of pore space evolution. Applied Geochemistry 26, 2159-2171. 
617 Gaboreau, S., Robinet, J.-C., Prêt, D., 2016. Optimization of pore-network characterization of a 618 compacted clay material by TEM and FIB/SEM imaging. Microporous and Mesoporous Materials 224, $619 \quad 116-128$.

620 Gens, A., Valleján, B., Sánchez, M., Imbert, C., Villar, M., Van Geet, M., 2011. Hydromechanical behaviour of a heterogeneous compacted soil: experimental observations and modelling. Géotechnique 61, 367-386.

623 Gouy, G., 1917. Sur la fonction électrocapillaire. Ann. Phys.(Paris) 7, 129-184.

624 Gouy, M., 1910. Sur la constitution de la charge electrique a la surface d'un electrolyte. J. Phys. Theor. 625 Appl. 9, 457-468.

626 Harjupatana, T., Alaraudanjoki, J., Kataja, M., 2015. X-ray tomographic method for measuring threedimensional deformation and water content distribution in swelling clays. Applied Clay Science 114, 386-394.

Holmboe, M., Wold, S., Jonsson, M., 2012. Porosity investigation of compacted bentonite using XRD profile modeling. Journal of contaminant hydrology 128, 19-32.

Holzer, L., Münch, B., Rizzi, M., Wepf, R., Marschall, P., Graule, T., 2010. 3D-microstructure analysis of hydrated bentonite with cryo-stabilized pore water. Applied Clay Science 47, 330-342. Ichikawa, Y., Kawamura, K., Theramast, N., Kitayama, K., 2004. Secondary and tertial consolidation of bentonite clay: consolidation test, molecular dynamics simulation and multiscale homogenization analysis. Mechanics of Materials 36, 487-513. Imbert, C., Villar, M.V., 2006. Hydro-mechanical response of a bentonite pellets/powder mixture upon infiltration. Applied Clay Science 32, 197-209. highly compacted bentonite. Physics and Chemistry of the Earth, Parts A/B/C 36, 1554-1558.

640 Karnland, O., Nilsson, U., Weber, H., Wersin, P., 2008. Sealing ability of Wyoming bentonite pellets 641 foreseen as buffer material - Laboratory results. Physics and Chemistry of the Earth, Parts A/B/C 33, 642 Supplement 1, S472-S475.

643 Karnland, O., Olsson, S., Nilsson, U., 2006. Mineralogy and sealing properties of various bentonites and 644 smectite-rich clay materials. SKB Stockholm. 
645

646

647

648

649

650

651

652

653

654

655

656

657

658

659

660

661

662

663

664

665

666

667

668

669

670

671

Karnland, O., Olsson, S., Nilsson, U., Sellin, P., 2007. Experimentally determined swelling pressures and geochemical interactions of compacted Wyoming bentonite with highly alkaline solutions. Physics and Chemistry of the Earth, Parts A/B/C 32, 275-286.

Kaufhold, S., Baille, W., Schanz, T., Dohrmann, R., 2015. About differences of swelling pressure dry density relations of compacted bentonites. Applied Clay Science 107, 52-61.

Keller, L.M., Schuetz, P., Erni, R., Rossell, M.D., Lucas, F., Gasser, P., Holzer, L., 2013. Characterization of multi-scale microstructural features in Opalinus Clay. Microporous and Mesoporous Materials 170, 83-94.

Kjellander, R., Marčelja, S., Quirk, J.P., 1988. Attractive double-layer interactions between calcium clay particles. Journal of Colloid and Interface Science 126, 194-211.

Komine, H., Ogata, N., 1994. Experimental study on swelling characteristics of compacted bentonite. Canadian Geotechnical Journal 31, 478-490.

Komine, H., Ogata, N., 1996. Prediction for swelling characteristics of compacted bentonite. Canadian Geotechnical Journal 33, 11-22.

Komine, H., Ogata, N., 2003. New equations for swelling characteristics of bentonite-based buffer materials. Canadian Geotechnical Journal 40, 460-475.

Komine, H., Yasuhara, K., Murakami, S., 2009. Swelling characteristics of bentonites in artificial seawater. Canadian Geotechnical Journal 46, 177-189.

Kozaki, T., Sato, Y., Nakajima, M., Kato, H., Sato, S., Ohashi, H., 1999. Effect of particle size on the diffusion behavior of some radionuclides in compacted bentonite. Journal of Nuclear Materials 270, 265-272.

Kozaki, T., Suzuki, S., Kozai, N., Sato, S., Ohashi, H., 2001. Observation of Microstructures of Compacted Bentonite by Microfocus X-Ray Computerized Tomography (Micro-CT). Journal of Nuclear Science and Technology 38, 697-699.

Laird, D.A., 2006. Influence of layer charge on swelling of smectites. Applied Clay Science 34, 74-87. Laird, D.A., Shang, C., Thompson, M.L., 1995. Hysteresis in Crystalline Swelling of Smectites. Journal of Colloid and Interface Science 171, 240-245. 
672 Likos, W.J., Wayllace, A., 2010. Porosity evolution of free and confined bentonites during interlayer 673 hydration. Clays and Clay Minerals 58, 399-414.

674 Liu, L., 2013. Prediction of swelling pressures of different types of bentonite in dilute solutions. Colloids 675 and Surfaces A: Physicochemical and Engineering Aspects 434, 303-318.

676 Lloret, A., Villar, M.V., Sanchez, M., Gens, A., Pintado, X., Alonson, E.E., 2003. Mechanical behaviour 677 of heavily compacted bentonite under high suction changes. Géotechnique 53, 27-40.

678 Madsen, F.T., Müller-Vonmoos, M., 1989. The swelling behaviour of clays. Applied Clay Science 4, $679 \quad 143-156$.

680 Meleshyn, A., Bunnenberg, C., 2005. The gap between crystalline and osmotic swelling of Na681 montmorillonite: A Monte Carlo study. The Journal of Chemical Physics 122, 034705.

682 Michot, L.J., Bihannic, I., Porsch, K., Maddi, S., Baravian, C., Mougel, J., Levitz, P., 2004. Phase diagrams of Wyoming Na-montmorillonite clay. Influence of particle anisotropy. Langmuir 20, 1082968410837.

685 686

Michot, L.J., Bihannic, I., Thomas, F., Lartiges, B.S., Waldvogel, Y., Caillet, C.l., Thieme, J., Funari, S.r.S., Levitz, P., 2013. Coagulation of Na-montmorillonite by inorganic cations at neutral pH. A combined transmission X-ray microscopy, small angle and wide angle X-ray scattering study. Langmuir 29, 3500-3510.

Norrish, K., 1954. The swelling of montmorillonite. Discussions of the Faraday Society 18, 120-134.

Orsini, L., Rémy, J., 1976. The use of the chloride of cobaltihexamine for the simultaneous determination of the exchange capacity and exchangeable bases in soils. Sci. Sol 4, 269-275.

Perdrial, J.N., Warr, L.N., 2011. Hydration behavior of MX80 bentonite in a confined-volume system: implications for backfill design. Clays and Clay Minerals 59, 640-653.

Prêt, D., 2003. Nouvelles méthodes quantitatives de cartographie de la minéralogie et de la porosité dans les matériaux argileux : application aux bentonites compactées des barrières ouvragées. Université de Poitiers, Poitiers, pp. [9]-242-[220] p.

Prêt, D., Sammartino, S., Beaufort, D., Fialin, M., Sardini, P., Cosenza, P., Meunier, A., 2010a. A new method for quantitative petrography based on image processing of chemical element maps: Part II. Semi-quantitative porosity maps superimposed on mineral maps, American Mineralogist, p. 1389. 
Prêt, D., Sammartino, S., Beaufort, D., Meunier, A., Fialin, M., Michot Laurent, J., 2010b. A new method for quantitative petrography based on image processing of chemical element maps: Part I. Mineral mapping applied to compacted bentonites, American Mineralogist, p. 1379.

Prêt, D., Sardini, P., Beaufort, D., Zellagui, R., Sammartino, S., 2004. Porosity distribution in a clay gouge by image processing of 14C-PolyMethylMethAcrylate (14C-PMMA) autoradiographs:: Case study of the fault of St. Julien (Basin of Lodève, France). Applied Clay Science 27, 107-118.

Pusch, R., 1982. Mineral-water interactions and their influence on the physical behavior of highly compacted Na bentonite. Canadian Geotechnical Journal 19, 381.

Pusch, R., 1999. Experience from preparation and investigation of clay microstructure. Engineering Geology 54, 187-194.

Pusch, R., Schomburg, J., 1999. Impact of microstructure on the hydraulic conductivity of undisturbed and artificially prepared smectitic clay. Engineering Geology 54, 167-172.

Pusch, R., Yong, R., 2003. Water saturation and retention of hydrophilic clay buffer-microstructural aspects. Applied Clay Science 23, 61-68.

Pusch, R., Yong, R.N., 2006. Microstructure of smectite clays and engineering performance. CRC Press. Rinnert, E., Carteret, C., Humbert, B., Fragneto-Cusani, G., Ramsay, J.D., Delville, A., Robert, J.-L., Bihannic, I., Pelletier, M., Michot, L.J., 2005. Hydration of a synthetic clay with tetrahedral charges: a multidisciplinary experimental and numerical study. The Journal of Physical Chemistry B 109, 2374523759.

Saiyouri, N., Tessier, D., Hicher, P.Y., 2004. Experimental study of swelling in unsaturated compacted clays. Clay Minerals 39, 469-479.

Sammartino, S., Siitari-Kauppi, M., Meunier, A., Sardini, P., Bouchet, A., Tevissen, E., 2002. An Imaging Method for the Porosity of Sedimentary Rocks: Adjustment of the PMMA Method--Example of a Characterization of a Calcareous Shale. Journal of Sedimentary Research 72, 937-943.

Santamarina, J., Klein, K., Palomino, A., Guimaraes, M., 2002. Micro-scale aspects of chemicalmechanical coupling-interparticle forces and fabric. Chemical Behaviour: Chemo-Mechanical Coupling from Nano-Structure to Engineering Applications, 47-64. 
Sardini, P., El Albani, A., Pret, D., Gaboreau, S., Siitari-Kauppi, M., Beaufort, D., 2009. Mapping and quantifying the clay aggregate microporosity in medium-to coarse-grained sandstones using the 14CPMMA method. Journal of Sedimentary Research 79, 584-592.

Sato, H., 2008. Thermodynamic model on swelling of bentonite buffer and backfill materials. Physics and Chemistry of the Earth, Parts A/B/C 33, Supplement 1, S538-S543.

Sato, H., Ashida, T., Kohara, Y., Yui, M., Sasaki, N., 1992. Effect of dry density on diffusion of some radionuclides in compacted sodium bentonite. Journal of Nuclear Science and Technology 29, 873-882. Schanz, T., Tripathy, S., 2009. Swelling pressure of a divalent-rich bentonite: Diffuse double-layer theory revisited. Water Resources Research 45, W00C12.

Segad, M., Jonsson, B., Åkesson, T., Cabane, B., 2010. Ca/Na montmorillonite: structure, forces and swelling properties. Langmuir 26, 5782-5790.

Sheppard, A.P., Sok, R.M., Averdunk, H., 2004. Techniques for image enhancement and segmentation of tomographic images of porous materials. Physica A: Statistical Mechanics and its Applications 339, $145-151$.

Sridharan, A., Rao, A.S., Sivapullaiah, P.V., 1986. Swelling pressure of clays. Geotechnical Testing Journal 9, 24-31.

Stern, O., 1924. Zur theorie der elektrolytischen doppelschicht. Zeitschrift für Elektrochemie und angewandte physikalische Chemie 30, 508-516.

Studds, P., Stewart, D., Cousens, T., 1998. The effects of salt solutions on the properties of bentonitesand mixtures. Clay Minerals 33, 651-660.

Tabtiang, A., Lumlong, S., Venables, R.A., 2000. The influence of preparation method upon the structure and relaxation characteristics of poly(methyl methacrylate)/clay composites. European Polymer Journal 36, 2559-2568.

Tang, C.S., Tang, A.M., Cui, Y.J., Delage, P., Schroeder, C., De Laure, E., 2011. Investigating the swelling pressure of compacted crushed-Callovo-Oxfordian claystone. Physics and Chemistry of the Earth, Parts A/B/C 36, 1857-1866.

Tisot, J.-P., 1974. Compactage et propriétés des matériaux compactés, application aux marnes du Keuper de Lorraine. Institut National Polytechnique de Lorraine, France. 
Tomioka, S., Kozaki, T., Takamatsu, H., Noda, N., Nisiyama, S., Kozai, N., Suzuki, S., Sato, S., 2010. Analysis of microstructural images of dry and water-saturated compacted bentonite samples observed with X-ray micro CT. Applied Clay Science 47, 65-71.

Van Geet, M., Volckaert, G., Roels, S., 2005. The use of microfocus X-ray computed tomography in characterising the hydration of a clay pellet/powder mixture. Applied Clay Science 29, 73-87.

Villar, M.V., Gómez-Espina, R., Gutiérrez-Nebot, L., 2012. Basal spacings of smectite in compacted bentonite. Applied Clay Science 65-66, 95-105.

Villar, M.V., Lloret, A., 2008. Influence of dry density and water content on the swelling of a compacted bentonite. Applied Clay Science 39, 38-49.

Vincent, L., Soille, P., 1991. Watersheds in digital spaces: an efficient algorithm based on immersion simulations. Pattern Analysis and Machine Intelligence, IEEE Transactions on 13, 583-598.

Volckaert, G., Bernier, F., Alonso, E., Gens, A., Samper, J., Villar, M., Martin-Martin, P., Cuevas, J., Campos, R., Thomas, H., 1996. Thermal-hydraulic-mechanical and geochemical behaviour of the clay barrier in radioactive waste repositories(model development and validation). EUR(Luxembourg).

Wang, Q., Cui, Y.-J., Tang, A.M., Barnichon, J.-D., Saba, S., Ye, W.-M., 2013. Hydraulic conductivity and microstructure changes of compacted bentonite/sand mixture during hydration. Engineering Geology 164, 67-76.

Wang, Z., Liu, L., Neretnieks, I., 2011. A novel method to describe the interaction pressure between charged plates with application of the weighted correlation approach. The Journal of Chemical Physics 135, 244107.

Wilson, J., Cuadros, J., Cressey, G., 2004. An In Situ Time-Resolved XRD-PSD Investigation into NaMontmorillonite Interlayer and Particle Rearrangement During Dehydration. Clays and Clay Minerals 52, $180-191$.

Winter, M., Clarke, B., 2002. Methods for determining representative density-depth profiles using nuclear density gauges. Géotechnique 52, 519-525. 


\section{TABLES}

2

3 Table 1. Relevant features of Kunipia-G

Type

Smectite content

Accessory phases

Particle density $\left(\mathrm{Mg} / \mathrm{m}^{3}\right)$

CEC (mequiv/100g)

Exchangeable cations

Specific surface area, BET $\mathrm{H}_{2} \mathrm{O}$

$\left(\mathrm{m}^{2} / \mathrm{g}\right)$

Specific surface area, BET $\mathbf{N}_{2}\left(\mathbf{m}^{2} / \mathbf{g}\right) \quad 42$
Sodium smectite

$95 \%$

$1-2 \%$ carbonates

2-3\% quartz

2.71

115.0

91\% Na, 8\% Ca, 1\% K 
6 Table 2. Physical features of water and methyl methacrylate (MMA) at $20{ }^{\circ} \mathrm{C}$ (Blumstein,

7 1965; Prêt, 2003; Prêt et al., 2004; Siitari-Kauppi, 2002)

\begin{tabular}{lll}
\hline & Water & \multicolumn{1}{c}{ Methyl methacrylate } \\
& & (MMA) \\
\cline { 2 - 3 } Dipole moment (D) & 1.85 & 1.7 \\
Thickness (A) & 2.65 & 3.8 \\
Viscosity (mPa.s) & 1.002 & 0.584 \\
Density (g/cm ${ }^{3}$ ) & 0.998 & 0.94 \\
Dielectric constant (F/m) & 80 & 6.32 \\
Surface tension (N/m) & $72.10^{-3}$ & $28.10^{-3}$ \\
\hline
\end{tabular}


12 Table 3. Swelling pressure and normalized swelling pressure of various specimens at dry

13 density $1.40 \pm 0.02 \mathrm{Mg} / \mathrm{m}^{3}$ at peak and at steady state of the conducted tests

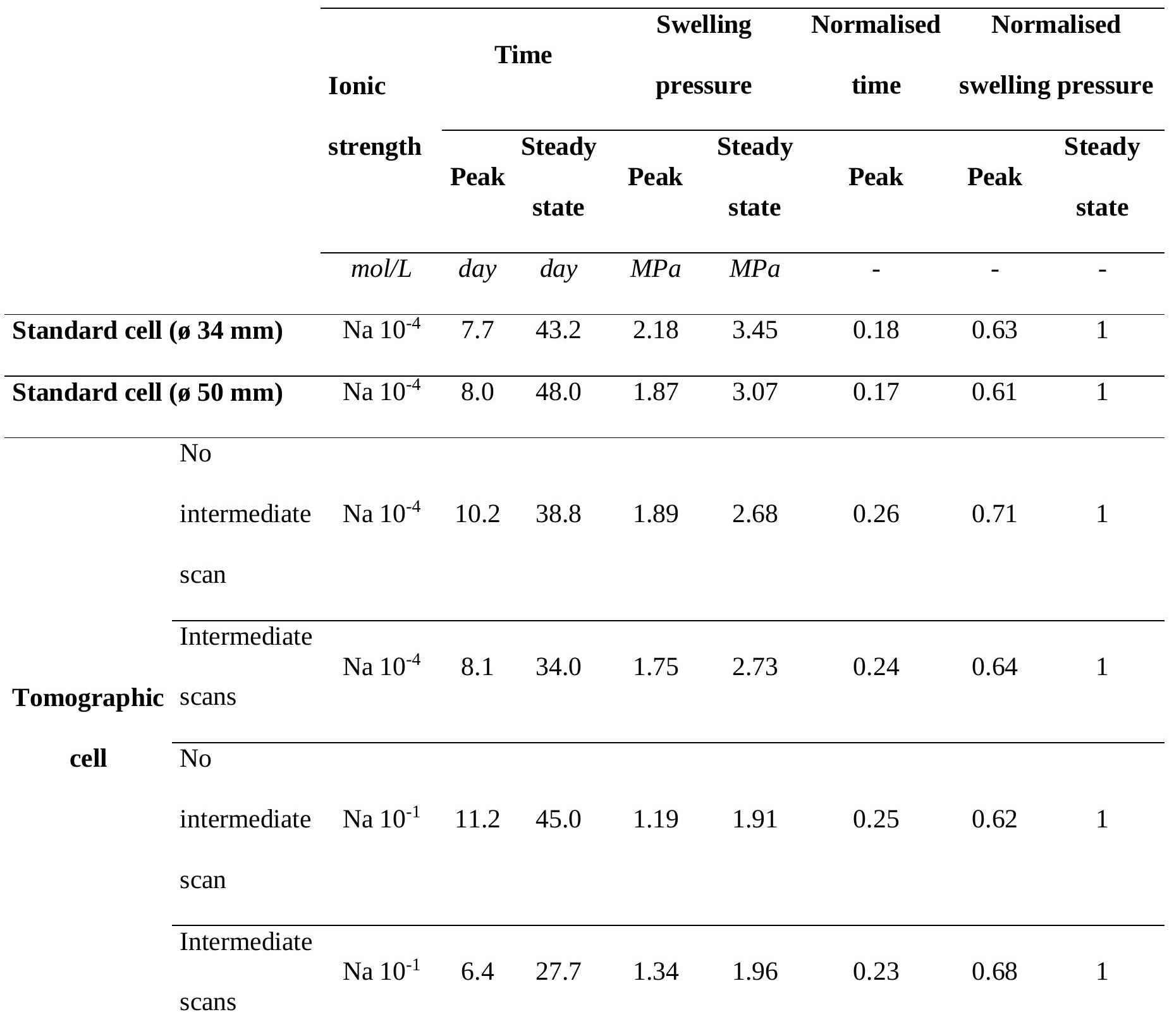


16 Table 4. Mean inter-aggregate porosity (\%) of specimens at dry density $1.40 \pm 0.02 \mathbf{~ M g} / \mathrm{m}^{3}$

17 hydrated with $\mathrm{NaCl} 10^{-4} \mathrm{M}, \mathrm{NaCl} \mathbf{1 0}^{-1} \mathrm{M}$ and MMA using tomographic cell in the different 18 hydration states.

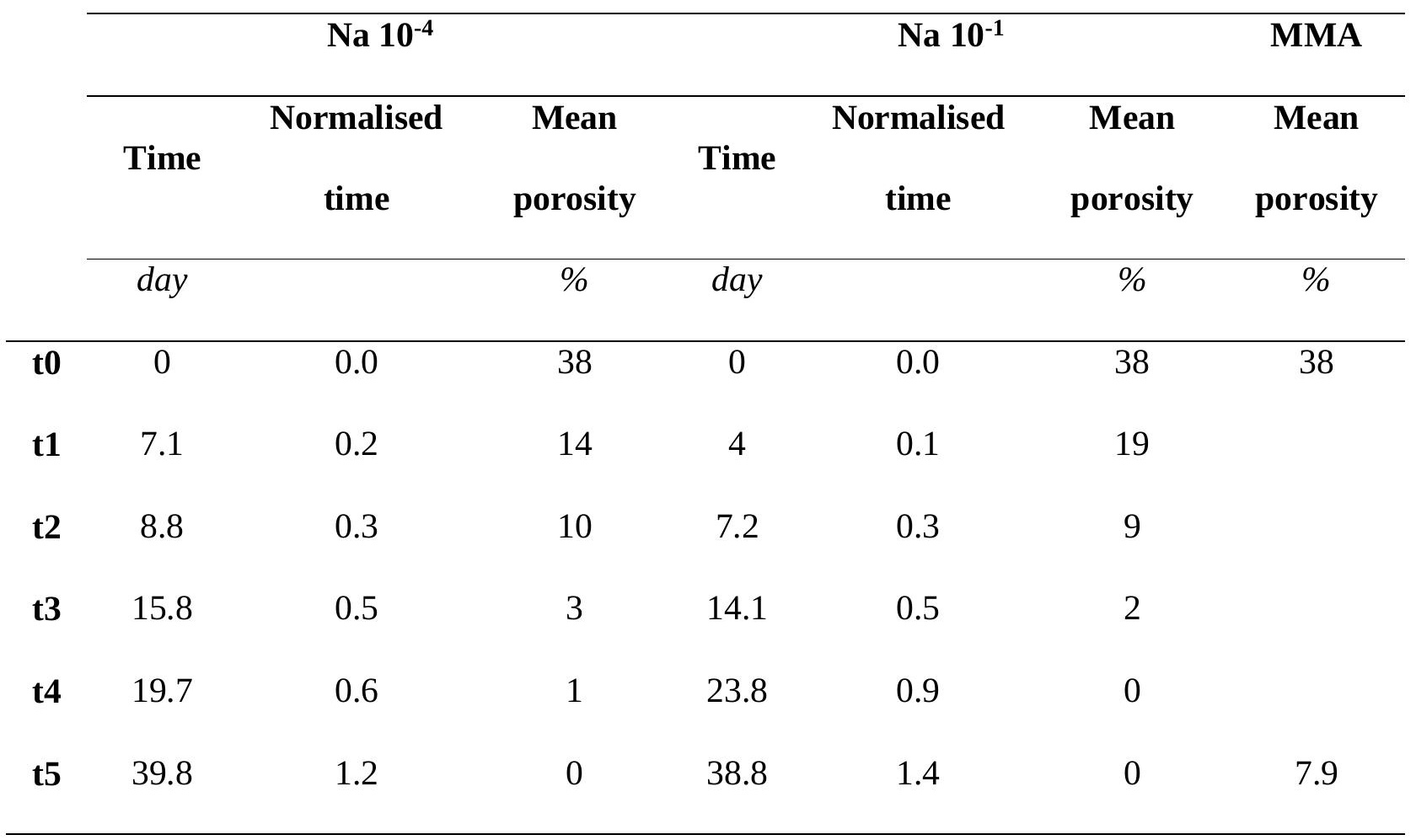


21 Table 5 Mean aperture radius of the inter-aggregate pores calculated from PSD of the 22 specimens hydrated by $\mathrm{NaCl} 10^{-4} \mathrm{M}$ and MMA. Calculations are performed in five ROIs 23 across the specimen height (Z-location: ROI1 0.5-2.3 mm, ROI2 2.3-4.1 mm, ROI3 4.1-5.9 $24 \mathrm{~mm}$, ROI4 5.9-7.7 mm, ROI5 7.7-9.5 mm). Only the data from the tomography stages t0, t1, t3 25 and 5 related to the images of the Figure 8 are given.

\begin{tabular}{|c|c|c|c|c|c|c|}
\hline \multicolumn{7}{|c|}{ Na10-4 } \\
\hline to & ROI1 & ROI2 & ROI3 & ROI4 & ROI5 & Mean \\
\hline Mean aperture radius $(\mu \mathrm{m})$ & 17.2 & 16.0 & 14.8 & 15.0 & 14.9 & 15.6 \\
\hline$t 1$ & ROI1 & ROI2 & ROI3 & ROI4 & ROI5 & Mean \\
\hline Mean aperture radius $(\mu \mathrm{m})$ & 8.0 & 9.6 & 10.9 & 11.8 & 11.9 & 10.4 \\
\hline t3 & ROI1 & ROI2 & ROI3 & ROI4 & ROI5 & Mean \\
\hline Mean aperture radius $(\mu \mathrm{m})$ & 7.9 & 7.8 & 7.8 & 8.1 & 8.2 & 8.0 \\
\hline$t 5$ & ROI1 & ROI2 & ROI3 & ROI4 & ROI5 & Mean \\
\hline Mean aperture radius $(\mu \mathrm{m})$ & 0 & 0 & 0 & 0 & 0 & 0 \\
\hline \multicolumn{7}{|c|}{ MMA } \\
\hline$t 5$ & ROI1 & ROI2 & ROI3 & ROI4 & ROI5 & Mean \\
\hline Mean aperture radius $(\mu \mathrm{m})$ & 8.3 & 8.2 & 8.0 & 8.0 & 7.8 & 8.1 \\
\hline
\end{tabular}




\section{Figure Captions}

Figure 1. Organisation of Kunipia-G across the different scales (from unit layer up to

4 centimetre scale)

Figure 2. X-ray diffraction patterns of Kunipia-G: (a) oriented X-ray diffraction patterns recorded under air-dried conditions, ethylene glycol hydration and heated at $550^{\circ} \mathrm{C}$, (b) capillary preparations in air-dried conditions and hydrated by MMA.

Figure 3. Representation of the new designed oedometer cell at constant volume: (a) schematic layout, (b) cell with upper piston unscrewed into load frame and (c) cell with upper piston screwed and installed into X-ray tomograph.

Figure 4. (a) VOI location inside the sample, (b) visualisation of sample porosity, (c) threshold value identified after the slope change of the first derivative of the grey-scale histogram, and comparison between raw and threshold images (d) in the vertical plane (YZ) and (e) in the horizontal plane (XY).

Figure 5. (a) Dimensionless evolution of swelling pressure in Kunipia-G specimens at the same dry density using standard cells and tomographic cell at dry density $1.40 \pm 0.02$ $\mathrm{Mg} / \mathrm{m3}$, (b) Swelling pressure at equilibrium versus Kunipia-G dry density compared to other swelling clay materials (MX-80, FEBEX bentonite).

Figure 6. Dimensionless evolution of swelling pressure of four specimens at dry density 1.40 $\pm 0.02 \mathrm{Mg} / \mathrm{m} 3$ subjected to $\mathrm{NaCl} 10-4 \mathrm{M}$ or $10-1 \mathrm{M}$ hydration for comparison between oedometer tests with or without tomography scans.

Figure 7. Swelling pressure evolution of specimens at dry density $1.40 \pm 0.02 \mathrm{Mg} / \mathrm{m} 3$ subjected to various fluid features using a tomographic cell. 
Figure 8. Inter-aggregate porosity evolution of specimens wetted with $\mathrm{NaCl} 10-4 \mathrm{M}, \mathrm{NaCl} 10$ $1 \mathrm{M}$ solutions or MMA at specific stages using tomographic cells: X-ray tomography picture, scan time after hydration start, mean porosity.

Figure 9. Evolution of inter-aggregate porosity volume during hydration with (a) Na 10-4 M and (b) Na 10-1 M, and comparison of porosity profiles of specimens hydrated by $\mathrm{NaCl}$ solution and MMA at initial states and final state.

Figure 10. Schematic evolution of inter-aggregate porosity and swelling pressure upon sample hydration with (a) aqueous solution and (b) MMA.

Figure 11. (a) Crystalline swelling (PCSS), electrostatic (PDDL) molecular (PvdW) components and total swelling pressure modified from Liu (2013). Input parameters are modified with the Kunipia-G available data. (b) Electrostatic component based on Gouy-Chapman theory calculated for different $\mathrm{NaCl}$ ionic strength and MMA considering dilute ionic concentration. The coloured markers represent the experimental data acquired in this work.

Figure 12. Inter-aggregate porosity decrease versus time after wetting start at different height positions on the sample from experimental data (Kunipia-G) and computed data (FoCa) by Gens et al. (2011). 
- C Cations WV W T $21 / a^{0}{ }^{0}$ Unit layer

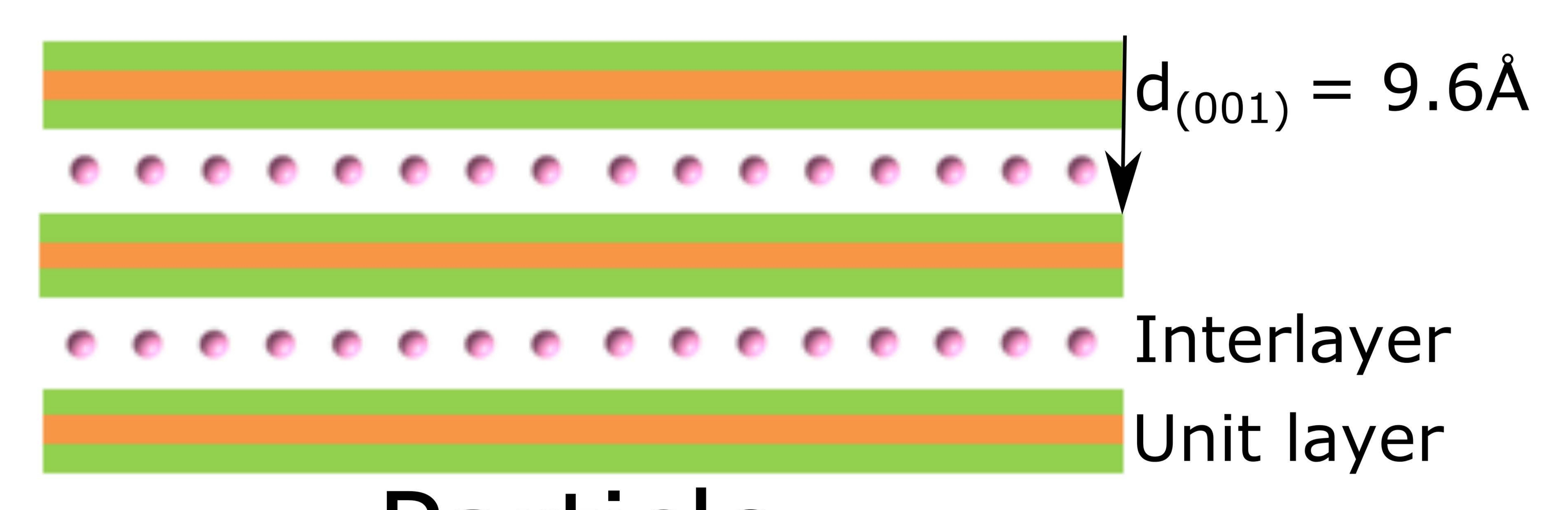

Particle

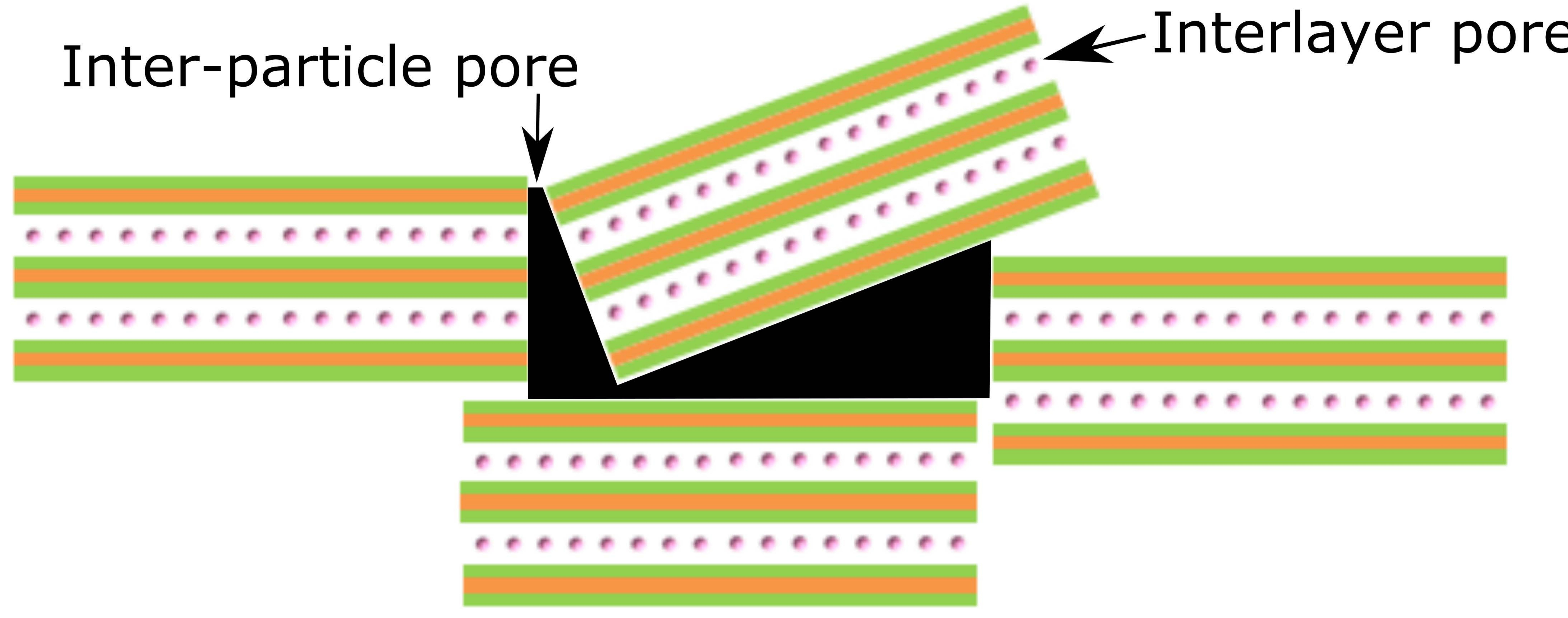

Pixel $(5 \mu \mathrm{m})$

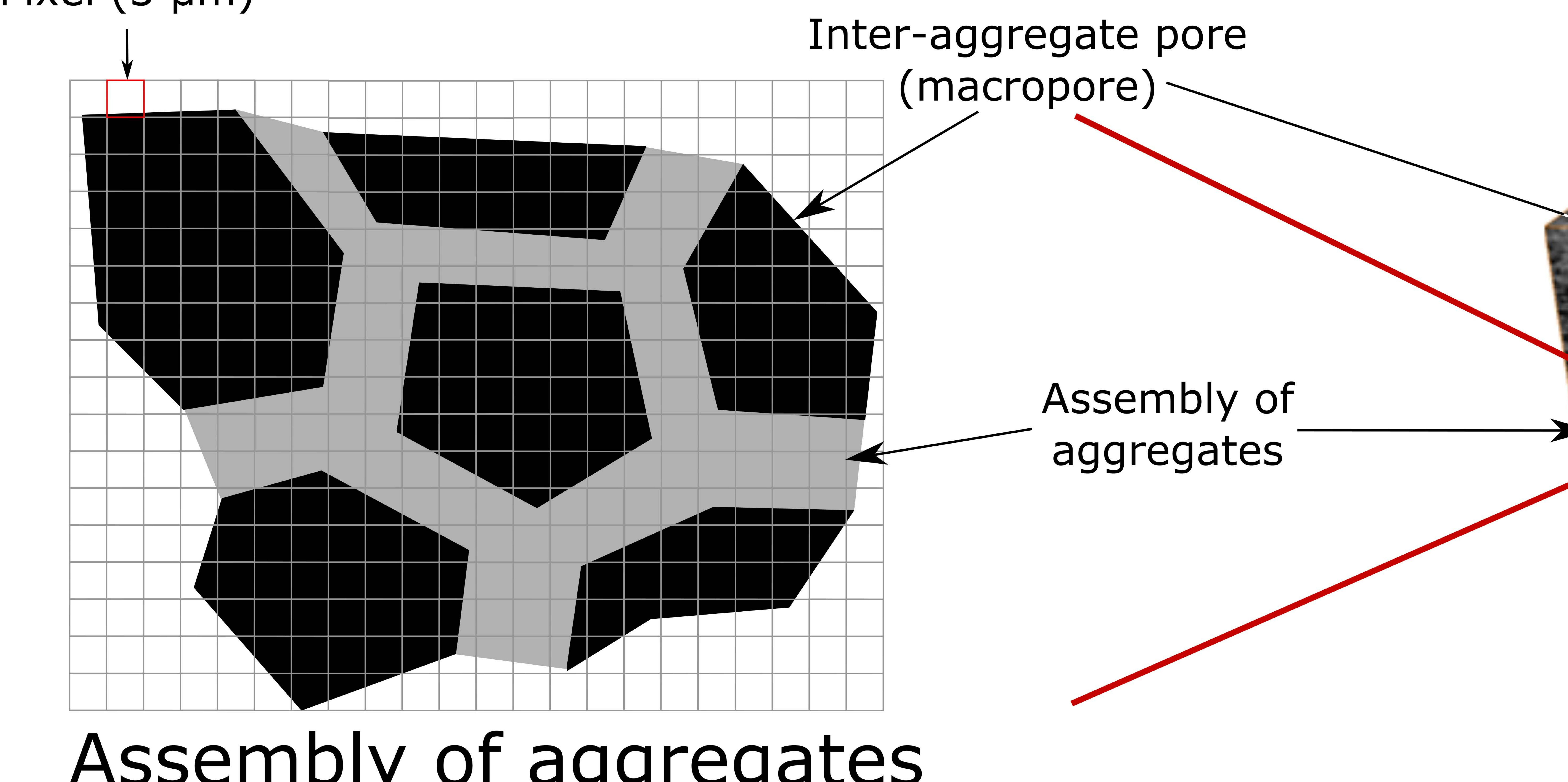

Aggregate
Assembly of aggregates 


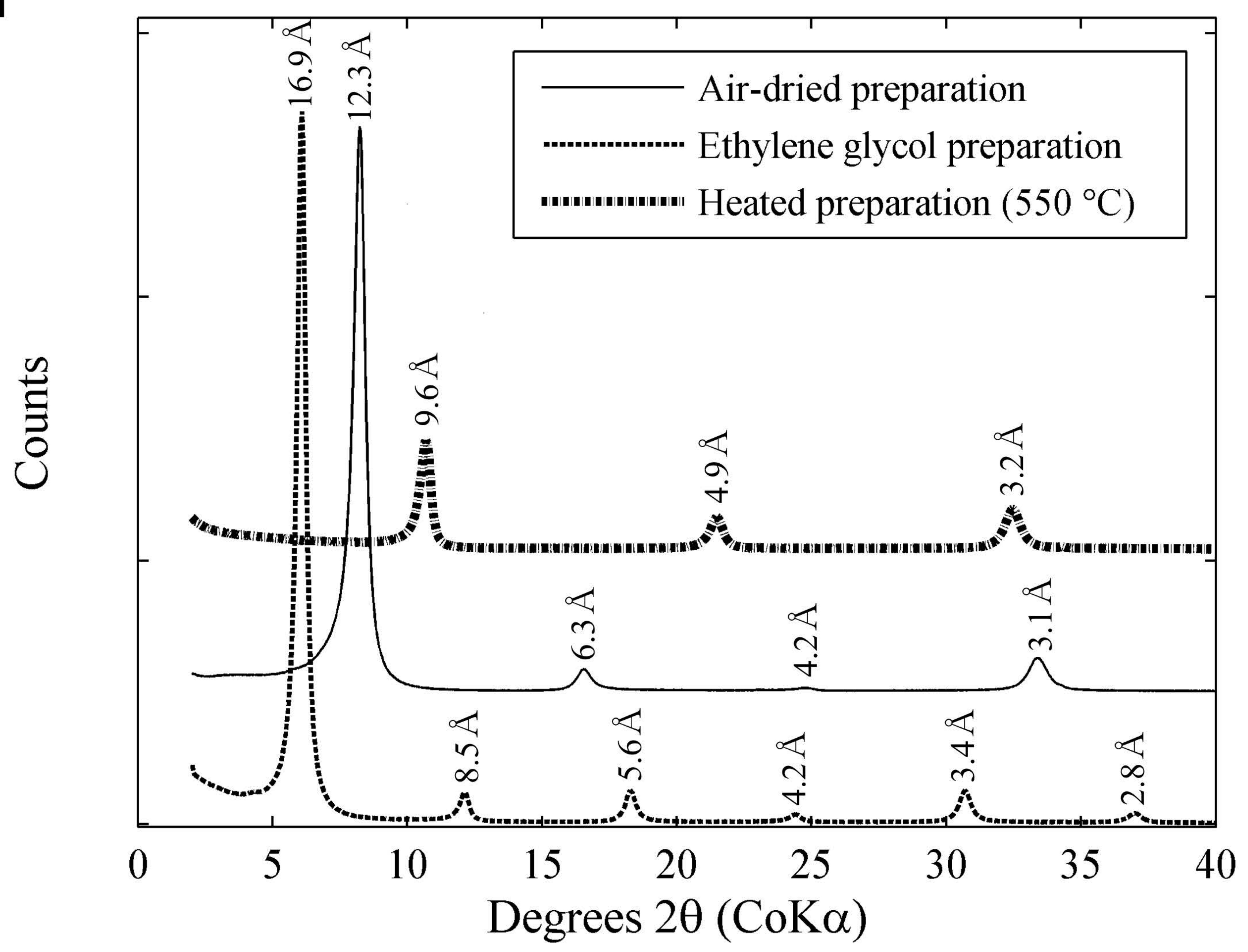



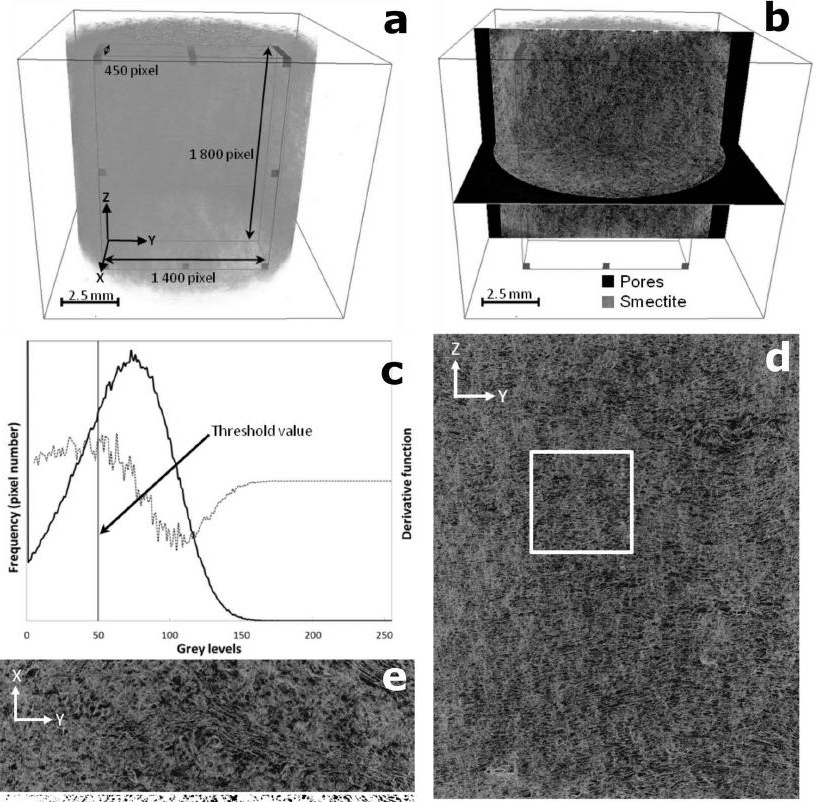

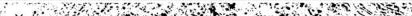
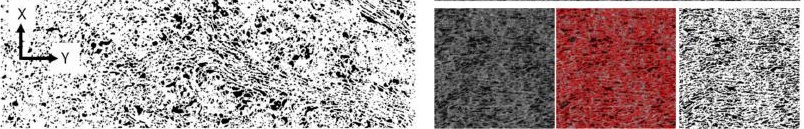


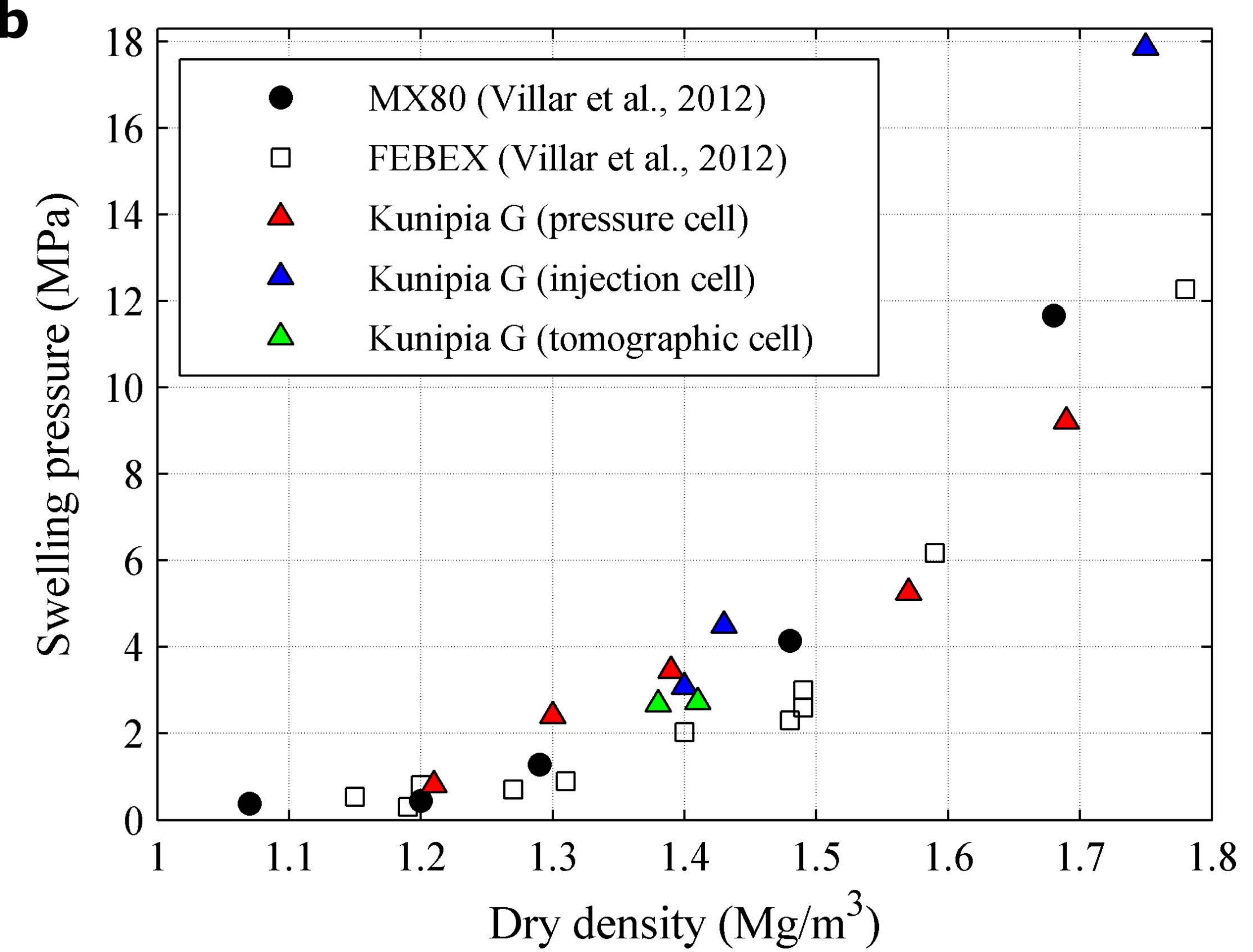




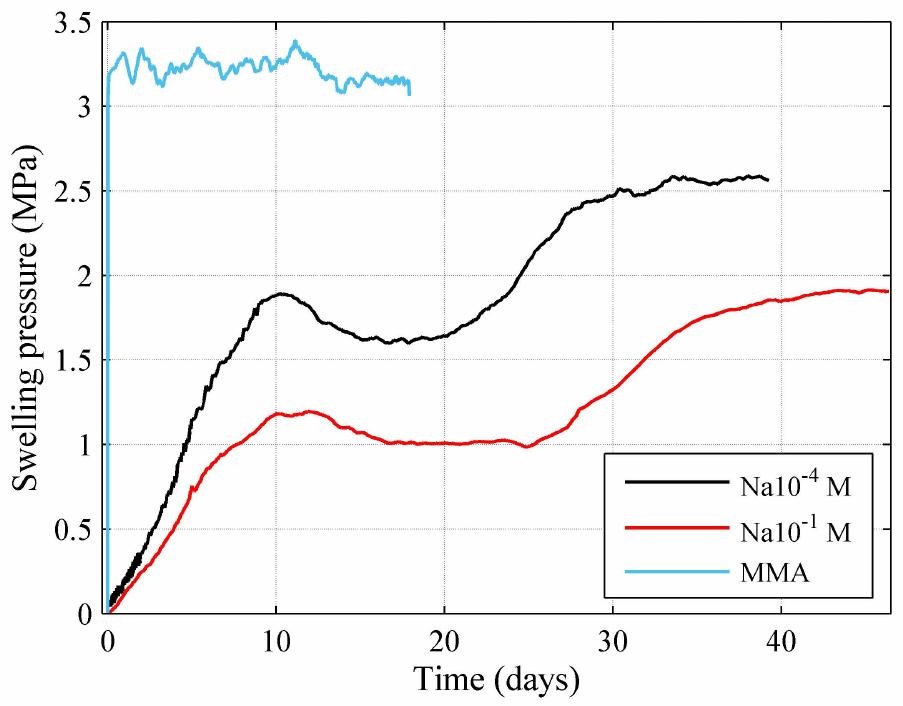




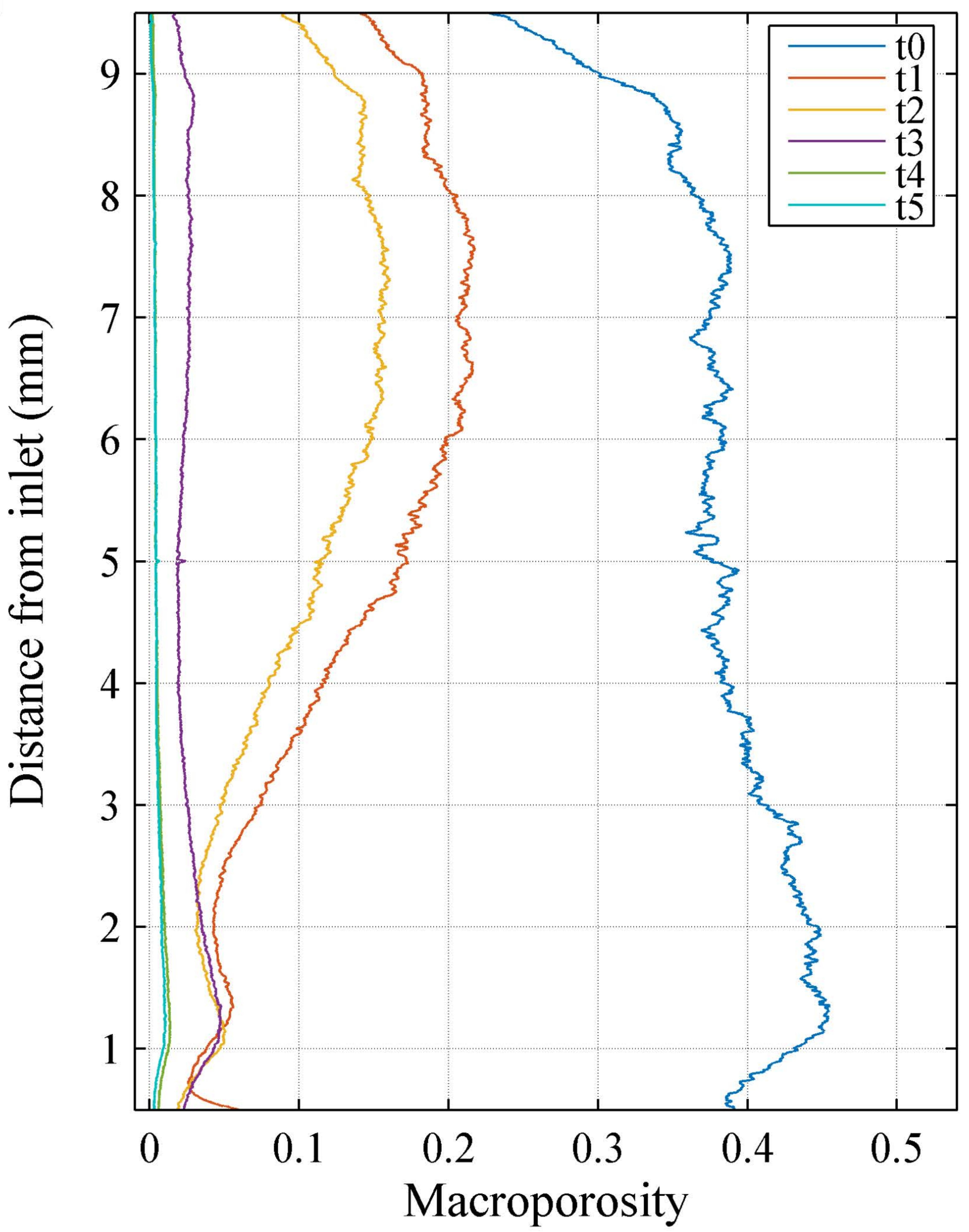




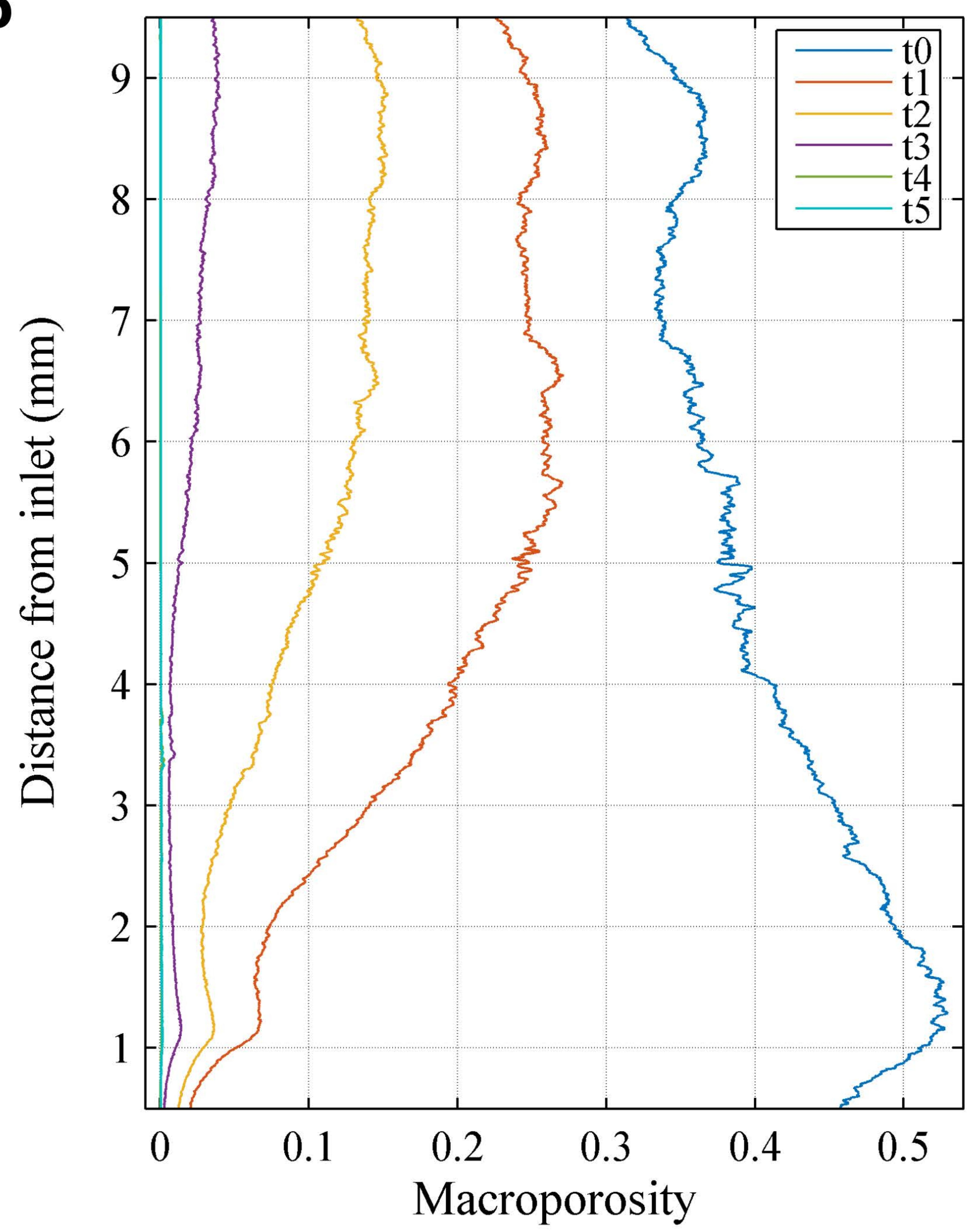


$\mathrm{Na} 10^{-4} \mathrm{M}(\mathrm{t} 0)$

$\mathrm{Na} 10^{-4} \mathrm{M}($ final state $=\mathrm{t} 5$ )

MMA (final state)

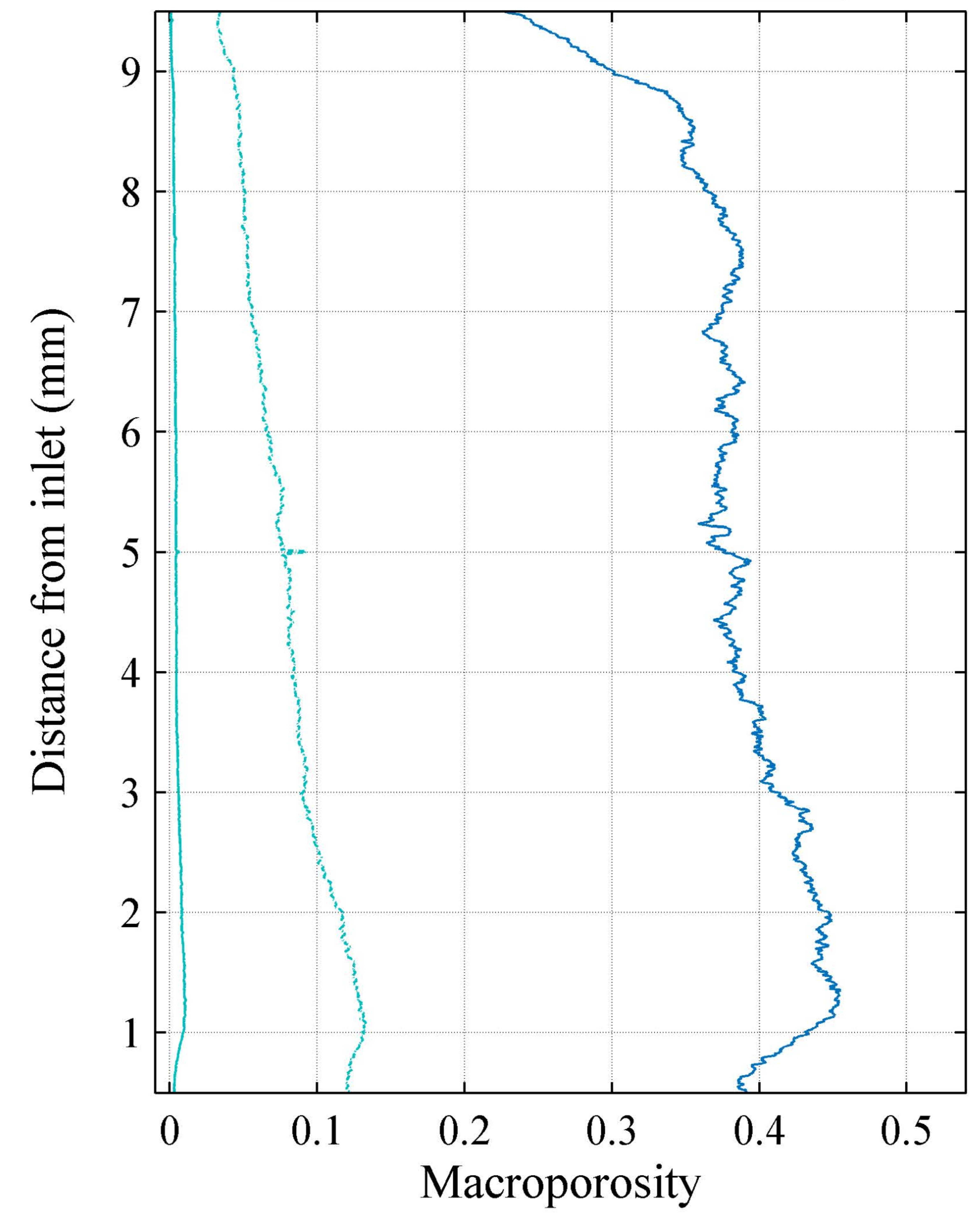

C 

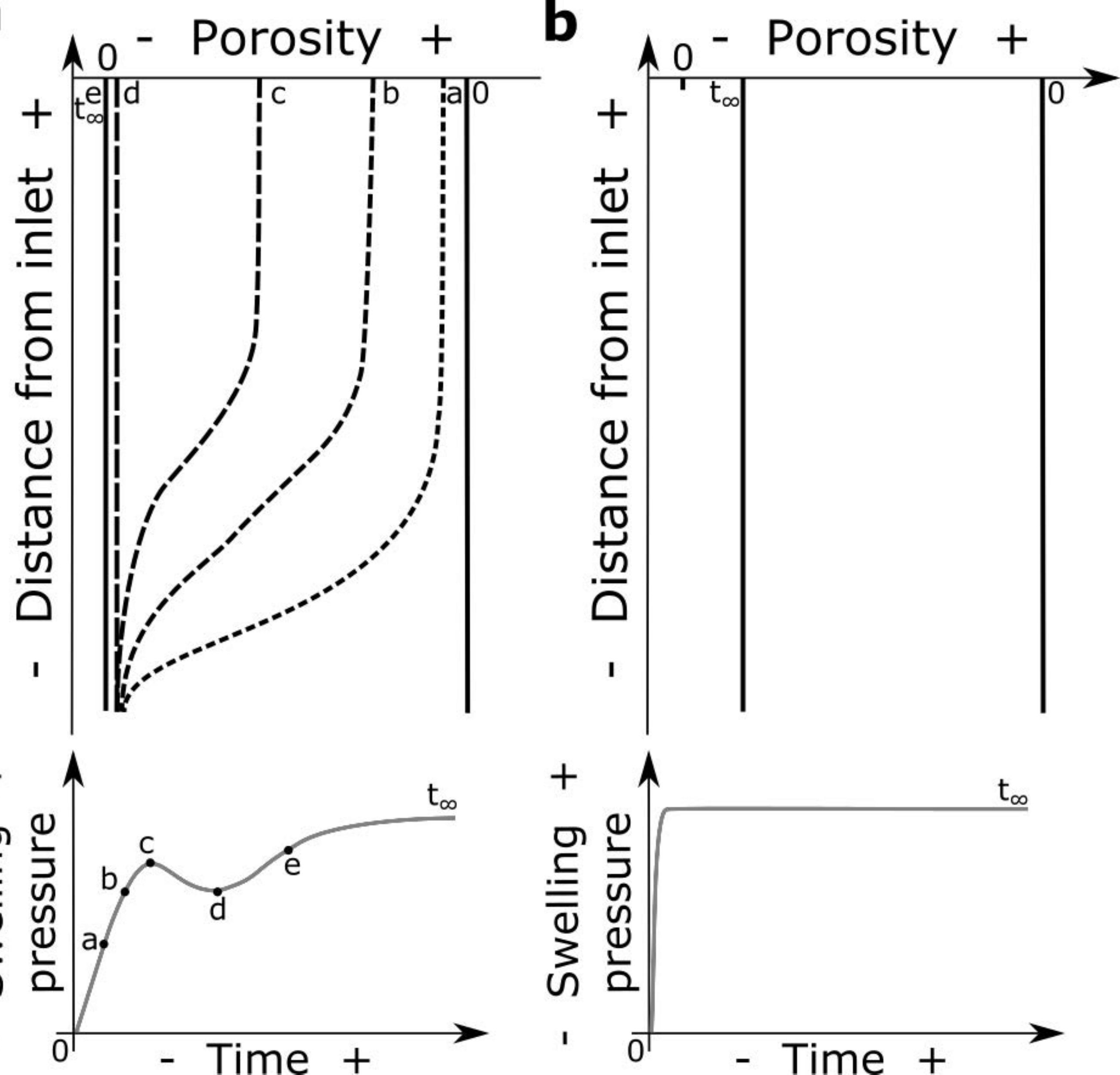


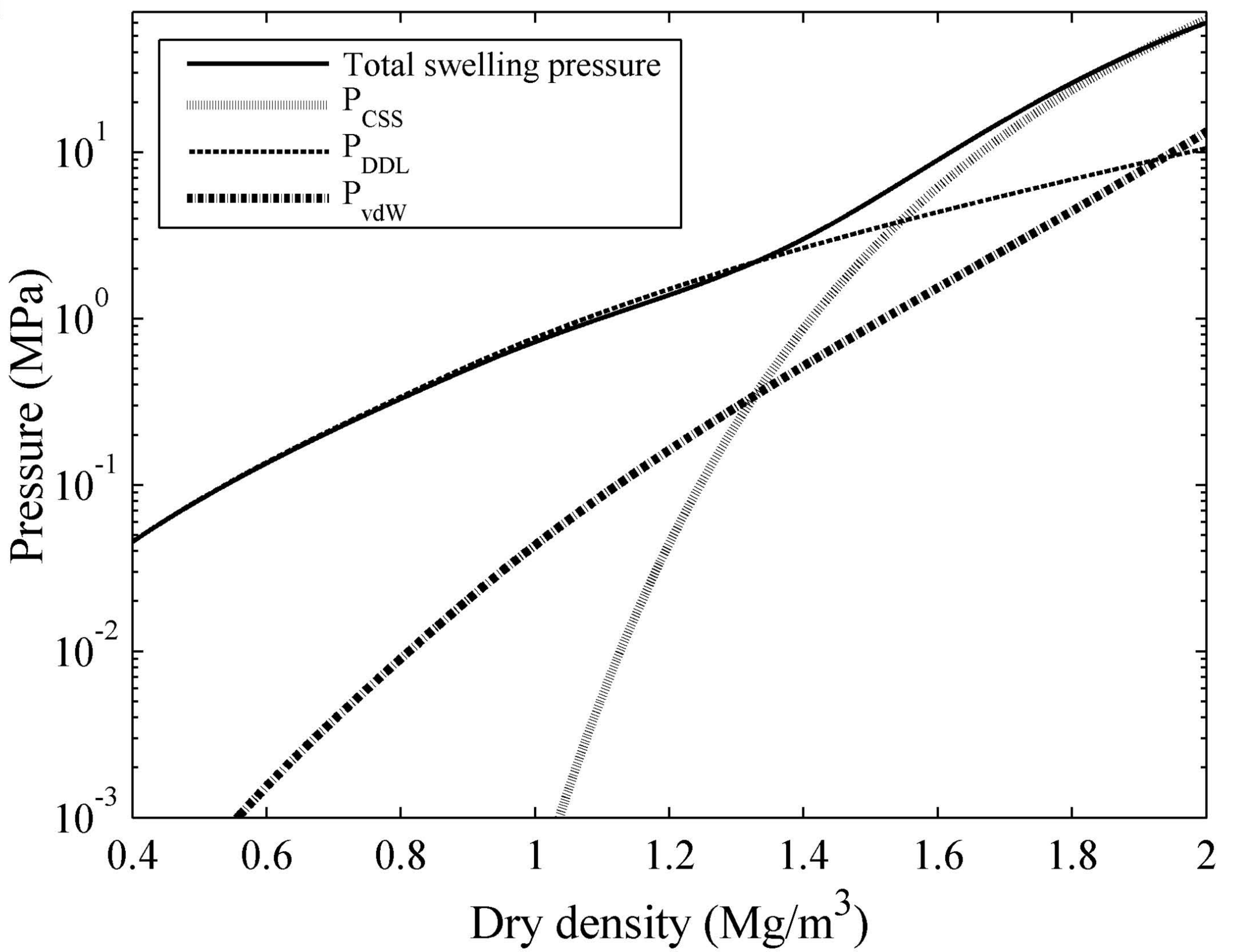




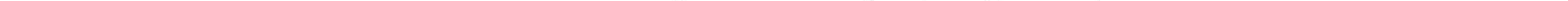




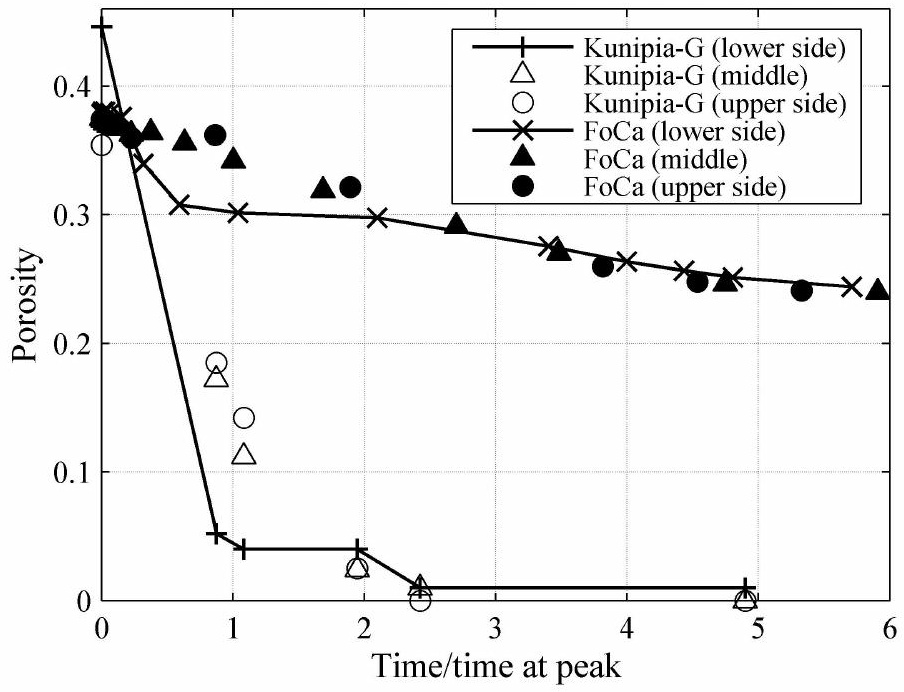

